\title{
Patterns and dynamics of dissolved organic carbon exports from a riparian zone of a temperate, forested catchment
}

\author{
Benedikt J. Werner ${ }^{1}$, Oliver J. Lechtenfeld ${ }^{2}$, Andreas Musolff ${ }^{1}$, Gerrit H. de Rooij ${ }^{3}$, Jie Yang ${ }^{1}$, Ralf
} Gründling $^{3}$, Ulrike Werban ${ }^{4}$, Jan H. Fleckenstein ${ }^{1}$

$5 \quad{ }^{1}$ Department of Hydrogeology, Helmholtz Centre for Environmental Research - UFZ, 04318 Leipzig, Germany

${ }^{2}$ Department of Analytical Chemistry, Research group BioGeoOmics, Helmholtz Centre for Environmental Research - UFZ, 04318 Leipzig, Germany

${ }^{3}$ Department of Soil System Sciences, Helmholtz Centre for Environmental Research - UFZ, 06120 Halle, Germany

${ }^{4}$ Department of Monitoring and Exploration Technologies, Helmholtz Centre for Environmental Research - UFZ, 04318

10 Leipzig, Germany

Correspondence to: Benedikt J. Werner (benedikt.werner@ufz.de)

Abstract. Export of dissolved organic carbon (DOC) from riparian zones (RZs) is an important, but poorly understood component of temperate catchment carbon budgets. This paper delineates explicit DOC source zones within the RZ of a small forested catchment in central Germany, and identifies and quantifies their dominant DOC export mechanism at high spatiotemporal resolution. Stream water DOC samples from differing hydrological situations were compared to riparian DOC groundwater and surface water samples and classified chemically (via Fourier-transform ion cyclotron resonance mass spectrometry) and spatially via a small-scale topographic analysis of the RZ at a resolution of $1 \mathrm{~m}$. Explicit water fluxes from the resulting riparian DOC source zones were then simulated by a physically-based, fully-integrated numerical flow model (HydroGeoSphere).

20 Chemical classification revealed two distinct DOC pools $\left(\mathrm{DOC}_{\mathrm{I}}\right.$ and $\left.\mathrm{DOC}_{\mathrm{II}}\right)$ in the $\mathrm{RZ}$. The comparison of stream and riparian water samples indicated a predominant export of $\mathrm{DOC}_{\mathrm{I}}$ during wet conditions and high groundwater levels. The two DOC pools were spatially separated and mapped using a threshold value in high-resolution topographical wetness index ( $\left.\mathrm{TWI}_{\mathrm{HR}}\right)$. Hydrological modelling revealed that surface runoff from $\mathrm{DOC}_{\mathrm{I}}$ source zones with high $\mathrm{TWI}_{\mathrm{HR}}$ values dominated overall discharge generation and therefore DOC export. Although corresponding to only $15 \%$ of the area in the studied RZ, the high $\mathrm{TWI}_{\mathrm{HR}}$ zones provided in total 1.5 times the load of DOC from the remaining $85 \%$ of the area associated with the $\mathrm{DOC}_{\text {II }}$ pool. Our results suggest that surface DOC export can play a dominant role for DOC export in RZs with overall low topographic relief and should be considered in DOC export models. We propose that proxies of spatial heterogeneity (here: $\mathrm{TWI}_{\mathrm{HR}}$ ) can delineate the most active riparian source zones and provide a meaningful basis for improved model conceptualization of surficial DOC export.

\section{Introduction}

Dissolved organic carbon (DOC) in streams and rivers is of central ecological importance (Cole et al., 2007; Battin et al., 2008), but amount and quality of DOC also shape water quality through interactions and co-export with other chemicals in 
terrestrial solute source areas (Ledesma et al., 2016; Sherene, 2010), rivers and lakes (Prairie, 2008). But despite increasing DOC concentrations in surface waters and shifting quality of exported DOC through ongoing changes in land use, climate and biogeochemical boundary conditions (Larsen et al., 2011; Chantigny, 2003; Wilson and Xenopoulos, 2008), routine management of DOC is practically nonexistent (Stanley et al., 2012), but could particularly help to fulfill water quality directives and increase cost efficiency of drinking water purification (Matilainen et al., 2011). In order to derive effective management practices, it is crucial to have an adequate conceptual understanding of the dominant mechanisms of carbon export (and nutrients in general) at scales that constitute the best compromise between conventional small-scale restoration projects and larger-scale water quality impairments by DOC (Stanley et al., 2012).

Especially riparian zones (RZs) of lower order streams are potential targets for DOC export management since RZs - as terrestrial aquatic interfaces - constitute a general control unit for DOC and solute export, lower order streams make up a large fraction of total river networks worldwide (Raymond et al., 2013) and their RZs represent a main source of terrestrial DOC export (Ledesma et al., 2015; Musolff et al., 2018). Large uphill contributing areas deliver a steady supply of water to the RZ, such that DOC mineralization and production of DOC mainly get limited by temperature and redox conditions, but not water content in the soil. Here, DOC accumulation rates are highest during anaerobic conditions at low temperatures due to low mineralization rates, whereas high mineralization rates can be realized in oxygen supplied soil compartments at higher temperatures. On the other hand, the rate of DOC accumulation and ultimately export is also dependent on hydrological connectivity of DOC sources to the stream. This leads to a stronger accumulation of DOC close to the soil surface where water mobilizes existing DOC pools only during hydrologic events. Thus topography of the hillslope-RZ continuum, initial groundwater level and precipitation are the main hydrological drivers for export from these DOC sources.

Attempts to acknowledge the spatio-temporal variability of underlying physical processes led to concepts like variable source zone activation (Dick et al., 2015; Werner et al., 2019), the dominant source layer (Ledesma et al., 2015) and transmissivity feedback (Bishop et al., 2004). These concepts still describe a heterogeneous system in terms of an integrated response with

55 a strong focus on vertical heterogeneity. But variations in lateral RZ width and spatio-temporal hydrological connectivity of single landscape units further influence DOC export in catchments (Ledesma et al., 2018a; Ploum et al., 2020; Dick et al., 2015). Moreover RZs are highly dynamic and heterogeneous with micro-topography inducing hot spots of biological activity (Frei et al., 2012) that contribute disproportionally strong to nutrient turnover and export when hydrologically connected to the stream (during hot moments). However, implementing this dynamic complexity including the adequate resolution for 60 spatio-temporal patterns of hot spots and hot moments within RZs into models still poses a challenge (Pinay et al., 2015; Bernhardt et al., 2017; Krause et al., 2014). Frei et al. (2010) could simulate and verify the evolution of biogeochemical hot spots and moments in a fully integrated, physically based model of a virtual RZ. However their model was computationally expensive and the implemented details potentially site specific. Hence the challenge remains to describe and quantify the lateral spatio-temporal variability of effective DOC export from RZs at larger management-scale, while at the same time being consistent with the local mechanisms that control DOC mobilization and transport. Model conceptualizations that are able to 
bridge those scales will be needed to up-scale DOC export to catchment-scale and beyond (Pinay et al., 2015; Detty and McGuire, 2010; Ledesma et al., 2016; Duncan et al., 2013).

An improved understanding of the dominant mechanisms in small-scale landscape elements could help to find accessible proxies that can describe the larger-scale effective DOC-export behavior of catchments (Frei et al., 2012; Grabs et al., 2012). Proxies based on landscape-scale characteristics like different land use types (Pisani et al., 2020), hydromapping based on convergence of topography (Laudon et al., 2016; Ploum et al., 2020), or topographical wetness (e.g. represented by the topographic wetness index TWI (Beven and Kirkby, 1979)) can potentially provide information on the distances and dominant connections of DOC source locations to the stream and thus DOC export at catchment-scale (Musolff et al., 2018; Fellman et al., 2017; Andersson and Nyberg, 2009; Inamdar and Mitchell, 2006; Grabs et al., 2012).

75 However, landscape- and catchment-scale proxies cannot differentiate DOC export mechanisms that are induced by the smallscale heterogeneity of topography and hydrological properties (e.g. micro-topography driven variable source zone contributions or spatial variability in biogeochemical DOC mobilization) because they integrate the entire RZ into a few spatial entities (e.g. model cells). For example, Andersson and Nyberg (2009) proposed a skewed linear relationship between mean catchment-scale TWI and DOC concentration for various Swedish catchments, which showed poor performance during dry hydrological states. We argue that a smaller-scale, dynamic assessment of the TWI, which includes the wetness conditions in the RZ could improve the quality of the DOC-TWI relationship by Anderson and Nyberg, as it would be able to account for the actual contributing source zones of DOC. We postulate that a small-scale assessment of the TWI in the RZ can identify dominant DOC source zones and their export dynamics, and in turn will yield better correlations between TWI values and instream DOC concentrations than catchment-scale TWI assessments.

85 Several powerful tools to assess topographical, biogeochemical and hydrological heterogeneities in riparian zones have become available over the years. High-resolution drone-based digital elevation models (DEMs) of study sites are now relatively easy to obtain and provide a more detailed perspective on small-scale topographical variations in the RZ that can be linked to potential DOC source areas and source apportionment. State-of-the-art techniques for molecular DOC characterization based on FT-ICR-MS allow to compare chemical fingerprints of DOC from different riparian source areas

90 with the integrated DOC signal in the stream (Raeke et al., 2017; Seifert et al., 2016; Wagner et al., 2019). Physico-chemical properties of the DOC compounds can provide valuable information on the origin, state of processing and mobilization potential of DOC, which can complement the identification of riparian DOC export patterns derived from topographic analysis. Last but not least, fully integrated, hydrogeological modeling can provide detailed insights into spatio-temporal patterns of small-scale hydrologic processes in the RZ (Frei et al., 2010). A systematic combination of these methods will

95 ultimately lead to an improved understanding of the dominant DOC source areas in RZs and the mobilization and hydrologic export of DOC from these areas to the stream. 
In this paper we identify dominant source areas of DOC within a riparian zone based on topographic analysis and DOC fingerprinting and evaluate the temporally variable export of DOC from these source areas to the stream using numerical flow modeling. To this end, we mapped and classified riparian DOC source areas and assessed DOC export to the stream within a highly instrumented RZ. More specifically, (1) chemical DOC fingerprints from different locations within a riparian zone were compared to the integrated DOC fingerprints in stream runoff under base flow and event flow conditions. (2) The DOC source areas identified in (1) were then mapped in space using high-resolution TWI to derive hot spots of DOC mobilization within the RZ. Finally, (3) we quantify the hydrological contribution of the delineated DOC source zones from (2) to stream flow generation and solute export using a numerical surface-subsurface water flow model. This approach allows us to develop a robust proxy to explicitly identify probable DOC source areas in riparian zones under different hydrological conditions, which could be used for mechanistically sound conceptualizations of catchment-scale, parsimonious DOC export models.

\section{Materials and Methods}

\subsection{Rappbode Catchment}

Measurements were conducted in a headwater catchment of the Rappbode stream (5139'22.61"N 1041'53.98"E, Fig. 1)

110 located in the Harz Mountains, Central Germany. After draining into a drinking water reservoir, the Rappbode stream flows into the river Bode, and discharges (through the rivers Saale and the Elbe) into the North Sea. The catchment has an area of $2.58 \mathrm{~km}^{2}$ and a drainage density of $2.91 \mathrm{~km} \mathrm{~km}^{-1}$. The study site is characterized by a temperate climate (Kottek et al., 2006), with a long-term mean air temperature of $6.0^{\circ} \mathrm{C}$ and mean annual precipitation of $831 \mathrm{~mm}$ (Stiege weather station $12 \mathrm{~km}$ away from the study site, data provided by the German Weather Service DWD). The uncultivated and uninhabited catchment is

115 predominantly forested with spruce and pine trees ( $77 \%), 11 \%$ is covered with grass, and $12 \%$ is covered by other vegetation and a few unpaved roads. Elevation ranges from 540 to $620 \mathrm{~m}$ above sea level; the mean topographic slope is $3.9^{\circ}$. The 90 th percentile of the topographic wetness index (TWI) as a measure for the extent of riparian wetlands in the catchment (Musolff et al., 2018) is 10.10 (median 7.58). The geology at this site consists mainly of graywacke, clay schist and diabase (Wollschläger et al., 2016). Soils in the spring area are dominated by peat and peat formation. Overall, $25 \%$ of the catchment soils are humic and stagnic gleysols that are connected to riparian zones. 


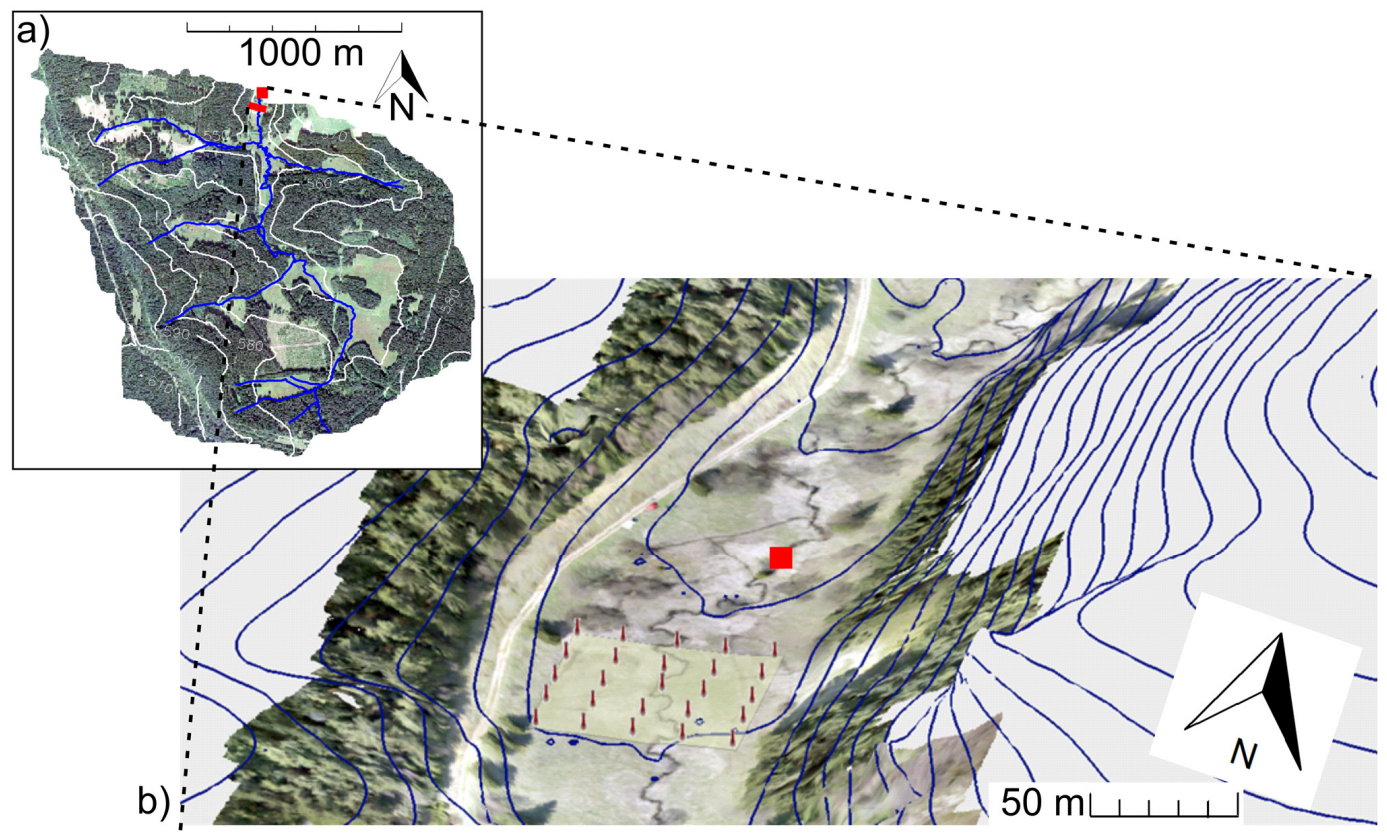

Figure 1. a) Rappbode catchment and position of the study site (red square). b) 3D view of the model site (red polygon). Soil sampling transect and piezometers network indicated by the red pins. Note the 2.5 -fold vertical exaggeration. Map data: $\odot$ Google, GeoBasisDE-BKG.

\subsection{The monitoring program}

The study site was chosen to be within the $90^{\text {th }}$ percentile of the Rappbode catchment TWI (derived from a drone-based high resolution DEM) and is thus regarded to be representative for riparian sites of the catchment (Musolff et al., 2018). Electric resistivity tomography (Resecs DC resistivity meter system, Kiel, Germany) was applied at two transects using a Wenner alpha configuration with an electrode distance of $0.5 \mathrm{~m}$ in order to explore structural consistencies of the subsurface. The intensive monitoring campaign took place from 12 April 2017 until 19 December 2018, the overall monitoring period lasted until 23 July 2019.

\subsubsection{In-stream data sensors}

Two PCM4 portable flow meters (Nivus, Germany) measured discharge in the Rappbode stream at a chosen inlet (PCM4 $\left.4_{\text {in }}\right)$ and outlet of the study site (PCM4 ${ }_{\text {out }}$ ), respectively. A pressure transducer (Solinst Levellogger, Canada) was installed in the center of the study site. All three probes measured water level every 15 minutes. Discharge at the center was then estimated via a stage-discharge relationship (stage was measured using a pressure transducer) which was established based on biweekly 
manual discharge measurements using an electromagnetic flow meter ( $n=37$; MF pro, Ott, Germany). Maximum discharge measured manually was $0.22 \mathrm{~m}^{3} \mathrm{~s}^{-1}$ on 28 February 2017 at a water level of $37.9 \mathrm{~cm}$. Manual measurements were recorded between 28 February 2017 and 19 December 2018. The extrapolation of the stage discharge relationship to a wider range of stages was found to be in a valid range (Werner et al., 2019). However, values larger than $0.22 \mathrm{~m}^{3} \mathrm{~s}^{-1}$ are more uncertain than smaller values.

\subsubsection{Weather station}

A weather station (WS-GP1, Delta-T, United Kingdom) was placed about $250 \mathrm{~m}$ northwest of the study site in order to characterize ambient weather conditions. Air temperature, humidity, wind direction and speed, solar radiation and rainfall were recorded at a $30 \mathrm{~min}$ interval. Potential evapotranspiration $\left(E T_{\mathrm{P}}\right)$ was calculated from the weather data after Penman-Monteith (Allen et al., 1998) also at a 30 minute resolution.

\subsubsection{Piezometer network}

The elevation map derived from the drone flight (Figure 1b) revealed that the floodplain's slope in the direction of the stream $(0.2 \mathrm{~m} / 10 \mathrm{~m})$ was steeper as the slope towards the stream $(0.1 \mathrm{~m} / 10 \mathrm{~m})$. We expected that this would have ramifications for the direction of the slope of the groundwater level and its temporal dynamics. To have maximum ability in capturing the magnitude and direction of this slope as a function of time a piezometer network was installed aligned on a square grid, with one principal axis oriented in parallel to the stream and the other perpendicular to the stream. Adjacent to the Rappbode stream, 25 partly screened piezometers $(2.54 \mathrm{~cm}$ diameter, HDPE, $10 \mathrm{~cm}$ screen) were installed in a rectangular grid pattern, comprising a piezometer network covering $3600 \mathrm{~m}^{2}(60 \mathrm{~m}$ x $60 \mathrm{~m}$, Figure 1b). The well spacing was $12.5 \mathrm{~m}$ in both principal directions of the grid. In addition 3 more wells were installed at $0.3 \mathrm{~m}$ depth inside the rectangular grid for surface near sampling. The A horizon in the piezometer holes was $17.7 \mathrm{~cm} \pm 2.4 \mathrm{~cm}$ on average $(n=27)$ (Figure 1). Figure S1 gives the depth of slotting and the soil horizon accessed by the slotted section. The screen depth of the piezometers ranged between $20 \mathrm{~cm}$ and $107 \mathrm{~cm}$ below ground (average $=75.2 \mathrm{~cm}$ ). This was a tradeoff between having continuous water level measurements from the pressure

160 transducers and covering the anticipated large variety of different DOC types in different soil layers and depths (Shen et al., 2015). Each piezometer was equipped with a pressure transducer (Levellogger, Solinst, Canada and Diver, van Essen, Netherlands), measuring at a 15-minute interval. All pressure transducers were barometrically corrected and adjusted to manual measurements of the groundwater level at 8 occasions during the 15 months measurement period (from 04 October 2017 to 19 December 2018).

\subsubsection{Sampling and maintenance}

Biweekly routine samples were collected in the Rappbode stream to determine DOC concentration. Riparian wells $(n=28)$, respective stream water samples and - if possible - riparian surface water samples were taken on five occasions throughout the year (Table S1). In addition, during five discharge-generating events, sampling in the stream was conducted hourly to sub- 
hourly by auto-samplers (6712 Full-Size Portable Sampler, Teledyne ISCO, US), which were triggered by the rate of water level increase. Bottles from the auto-sampler were soaked for $48 \mathrm{~h}$ in $0.1 \mathrm{~N} \mathrm{HCl}$ prior to use. Process blanks with deionized water were prepared to correct for eventual contaminations during field work and sample processing. Due to the remoteness of the study site, auto-sampled stream water samples were collected within 4 days after the triggered event sampling. Samples were stored in the dark inside the sampler and air temperatures were below $10^{\circ} \mathrm{C}$ during that time.

Riparian zone shallow groundwater samples were collected from 3 to 18 out of the 28 installed piezometers depending on hydrological conditions. Before sampling, water in the wells was replaced one to three times (based on the responsivity of the wells) through pumping. The flasks and the pump were rinsed with sample water prior to actual sampling. $100 \mathrm{~mL}$ of sample volume was then transferred into acid-rinsed $(0.1 \mathrm{~N} \mathrm{HCl})$ and baked $\left(500^{\circ} \mathrm{C}, 4 \mathrm{~h}\right)$ glass bottles and stored dark and cool until further processing in the laboratory.

\subsection{Chemical analysis}

\subsubsection{Sample processing and DOC determination}

After sample collection at the study site, samples were filtered using $0.45 \mu \mathrm{m}$ membrane filters (cellulose acetate filter, Th. Geyer, Germany) and acidified to $\mathrm{pH} 2(\mathrm{HCl}, 30 \%$, Merk, Germany) for subsequent DOC measurement and extraction. Filters were rinsed with $20 \mathrm{~mL}$ of sample water to avoid bleeding. Filtered samples were stored in the dark at $4{ }^{\circ} \mathrm{C}$ until laboratory analysis was conducted (typically within two days).

DOC concentration was determined as non-purgeable organic carbon with a high-temperature catalytic oxidation system (multi N/C 3100, Analytik Jena, Jena, Germany) from acidified samples and extracts after solvent evaporation. Due to the small difference in DOC concentration between hourly and subhourly samples during events we chose a lower time resolution for high resolution mass spectrometry measurements. A volume of $10-200 \mathrm{~mL}(n=142)$ was extracted via solid-phase extraction using an automated system (FreeStyle, LC Tech, Obertaufkirchen, Germany) on $50 \mathrm{mg}$ styrene-divinyl-polymer type sorbens (Bond Elut PPL, Agilent Technologies, Santa Clara, CA, United States) to desalt the sample for subsequent DI-ESI-MS according to Dittmar et al. (2008) and (Raeke et al., 2017). The carbon-to-sorbens ratio (C:PPL) was $280 \pm 130(\mathrm{~m} / \mathrm{m}, n=$ 142). The SPE-DOM was eluted with $1 \mathrm{~mL}$ methanol (Biosolve, Valkenswaard, The Netherlands), and stored at $-20^{\circ} \mathrm{C}$ until measurement. Carbon based extraction efficiency was ( $56 \pm 15) \%$ (determined from $n=133$ samples, Fig. S8). This is in the range of typical extraction efficiencies obtained for freshwater samples (Raeke et al., 2017). Immediately prior FT-ICR-MS analysis extracts were diluted to $20 \mathrm{ppm}$ and mixed 1:1 (v/v) with ultrapure water (Milli-Q Integral 5, Merck, Darmstadt, Germany).

\subsubsection{FT-ICR-MS measurement}

An FT-ICR mass spectrometer equipped with a dynamically harmonized analyzer cell (solariX XR, Bruker Daltonics Inc., Billerica, MA, USA) and a $12 \mathrm{~T}$ refrigerated actively shielded superconducting magnet (Bruker Biospin, Wissembourg, 
200 France) instrument was used in ESI negative mode (capillary voltage: $4.2 \mathrm{kV}$ ) using an Apollo II source. Extracts were analyzed in random order with an auto sampler (infusion rate: $10 \mu \mathrm{L} \mathrm{min}{ }^{-1}$ ). For each spectrum, 256 scans were co-added in the mass range $150-1000 \mathrm{~m} / \mathrm{z}$ with 4MW time domain (resolution@ @ $400 \mathrm{~m} / \mathrm{z}$ was ca. 483000). Mass spectra were internally re-calibrated with a list of peaks $(247-643 \mathrm{~m} / \mathrm{z}, \mathrm{n}>55)$ commonly present in terrestrial DOM and the mass accuracy after linear calibration was better than $0.13 \mathrm{ppm}(n=142)$. Peaks were considered if the signal-to-noise $(\mathrm{S} / \mathrm{N})$ ratio was greater than

205 four. Raw spectra were processed with Compass DataAnalysis 4.4 (Bruker Daltonics Inc., Billerica, MA, USA). SRFA reference sample and a pool sample (mix of randomly picked DOM extracts) was repeatedly measured to check instrument performance across multiple measurement days and solvent and extraction blanks were measured with the samples.

\subsubsection{FT-ICR-MS data processing}

Molecular formulas were assigned to peaks in the range $0-750 \mathrm{~m} / \mathrm{z}$ allowing for elemental compositions $\mathrm{C}_{1-60} \mathrm{H}_{0-122} \mathrm{~N}_{0-2} \mathrm{O}_{0-40} \mathrm{~S}_{0 \text { - }}$

2101 with an error range of $\pm 0.5 \mathrm{ppm}$ according to Herzsprung et al. (2020). Briefly, the following rules were applied: $0.3 \leq \mathrm{H} / \mathrm{C}$ $\leq 2.5,0 \leq \mathrm{O} / \mathrm{C} \leq 1,0 \leq \mathrm{N} / \mathrm{C} \leq 1.5,0 \leq \mathrm{DBE} \leq 25$ (double bound equivalent, $\mathrm{DBE}=1+1 / 2(2 \mathrm{C}-\mathrm{H}+\mathrm{N})$, Koch et al. (2014)), $-10 \leq \mathrm{DBE}-\mathrm{O} \leq 10$ (Herzsprung et al., 2014), and element probability rules proposed by Kind and Fiehn (2007). Isotopologue formulas $\left({ }^{13} \mathrm{C},{ }^{34} \mathrm{~S}\right)$ were used for quality control but removed from the final data set as they represent duplicate chemical information. All peaks present in the instrument blank and in the SPE blanks were subtracted from the mass list. Relative peak

215 intensities (RI) were calculated based on the summed intensities of all assigned peaks in each sample. To ensure that the variance in DOC quality observed by FT-ICR-MS was not induced by systematic instrumental shifts at different times of the year, we quantified the variability of peak intensities based on 15 reference samples (SRFA) of the four measurement days. Subsequently this variability was applied to every RI in measured samples to derive a mean error for the intensity (see S1). We conclude that the analytical uncertainty from the FT-ICR-MS measurements between the different measurement dates does only minor affect the overall variance of the samples, which allows the joint evaluation of all samples (see S1, Fig. S2, Fig. S3). An assigned molecular formula is termed compound throughout this article although they potentially represents multiple isomers.

\subsection{Numerical water flow modeling}

The numerical code HydroGeoSphere (HGS) was used to quantify flows at the study site. HydroGeoSphere is a 3D numerical model describing fully coupled surface-subsurface, variably saturated flow (Therrien et al., 2010). It solves Richards' equation for $3 \mathrm{D}$ variably saturated water flow in the subsurface domain, and uses Manning's equation and the diffusive-wave approximation of the St. Venant equations to simulate surface flow in the 2D surface domain and 1D channel network (Yang et al., 2015). Using a dual node coupling approach, HydroGeoSphere simulates the water exchange fluxes between the domains, providing the simulated infiltration/exfiltration fluxes. More details on the governing equations, coupling approach, and general aspects of HydroGeoSphere can be found in (Therrien et al., 2010). 
Only the upper $2 \mathrm{~m}$ of the alluvial sediments were included in the flow simulation as an aquifer because geological survey data showed that the electric resistivity dropped sharply below that depth indicating base rock formation (Fig. S4). The subsurface was discretized into 8 horizontal element-layers, each composed of 6924 prisms. The layer thicknesses ranged from $0.05 \mathrm{~m}$ near the land surface to $0.5 \mathrm{~m}$ near the aquifer bottom. The horizontal cell sizes varied from $1 \mathrm{~m}$ to $2 \mathrm{~m}$. The 6924 uppermost 2D triangles of the 3D prismatic mesh were used to discretize the surface domain. The channel crossing the study site was discretized into 148 1D segments, which coincide with the segments of the 2D triangular mesh. The line element made up of the channel segments was treated as a Cauchy boundary with the stream stage being calculated based on the assumption of a rectangular cross-section with channel width and depth based on measurements.

\subsubsection{Parameters}

240 Lateral variability of the saturated hydraulic conductivity $K$, i.e. the $K$ field in $x y$-plane, was calibrated using 38 pilot-points (Tang et al., 2017; Moeck et al., 2015) distributed inside the study site. Each of these pilot-points were associated with a $K$ value, set to $0.1 \mathrm{~m} \mathrm{~d}^{-1}$ prior to calibration. For the vertical $K$ heterogeneity, it was assumed that the $K$ was depth-dependent and decreased exponentially when the aquifer was deeper than $0.2 \mathrm{~m}$, as $K=K_{0}$ when $d<0.2 \mathrm{~m}$, and $K=K_{0} e^{-\lambda d} d>0.2 \mathrm{~m}$, where $K_{0}$ is the hydraulic conductivity of the aquifer top determined from the horizontal $K$ field, $d$ is the aquifer depth to land surface and $\lambda$ is a factor constraining the decreasing rate, set to 0 prior to calibration. These formulations captured the general decreasing trend of $K$ with depth, while also reflecting the fact that this decreasing trend was not significant in the upper 0.2 $\mathrm{m}$ of the soil, which contained most roots and mainly consisted of poorly decayed organic materials.

The surface domain and channel domain were uniformly parameterized with Manning roughness coefficients (Manning et al., 1890), respectively. Prior to calibration, the roughness coefficients were set to $6 \cdot 10^{-6} \mathrm{~d} \mathrm{~m}^{-1 / 3}$, a typical value for

250 floodplains/grassland. The parameters described above were selected as key parameters that could significantly influence the flow processes, and were optimized during calibration (Table S2). Other parameters were assigned for the model domain according to literature values from Yang et al. (2018) from a nearby $(25 \mathrm{~km})$ catchment with similar geological settings. Values were then adjusted during calibration (Table S2).

\subsubsection{Boundary and initial conditions}

Input data was defined at a one-hour time resolution for the simulation, and all the time-resolution data ( $15 \mathrm{~min})$ was aggregated accordingly. For the aquifer top boundary, spatially uniform and temporally variable precipitation was applied to the surface domain. Spatially uniform and temporally variable potential ET, estimated using the climate data, was specified as model input with actual ET being simulated by the model (Therrien et al., 2010). For the upstream boundary AB (Figure 2), a constant groundwater head gradient of 0.02 in the direction of the stream was assumed according to the measured groundwater levels, such that a groundwater flux $\left(Q_{u p}\right)$ entering the subsurface domain across AB could be determined using Darcy's law. A temporally variable flux $Q_{u p}^{c}$ was directly applied to the inlet of the channel domain, representing the measured channel discharge rate. The groundwater recharge rates via the two lateral boundaries of the model domain AD and BC $\left(Q_{\text {left, }} Q_{\text {right }}\right)$ 
https://doi.org/10.5194/hess-2021-82

Preprint. Discussion started: 23 February 2021

(c) Author(s) 2021. CC BY 4.0 License.

were estimated using $R \cdot A_{\text {con }}$, where $R$ is the annual mean groundwater recharge rate in this area $\left(\sim 200 \mathrm{~mm} \mathrm{yr}^{-1}\right)$, and $A_{\text {con }}$ is the contributing surface area associated with each lateral boundary estimated from the DEM. The respective recharge fluxes

$265 Q_{\text {left, }}$ and $Q_{\text {right }}$ were calculated as $0.18 \mathrm{~m}^{3} \mathrm{~s}^{-1}$ per unit length and $0.09 \mathrm{~m}^{3} \mathrm{~s}^{-1}$ per unit length. They were also allowed to vary by 0.1 to 10 times of their initial values during model calibration (Table S2). Water can exit the model domains through the downstream boundary $\mathrm{CD}$, either via the subsurface calculated using a constant groundwater head gradient of $0.02\left(Q_{\text {down }}\right)$, or via the surface domain $\left(Q_{\text {down }}^{o}\right)$ and channel outlet $\left(Q_{\text {down }}^{c}\right)$ calculated using a critical depth boundary condition (Therrien et al., 2010). All other model boundaries were assumed to be impermeable (no flow boundaries).

270 A steady state model was obtained by running a preliminary simulation using time-invariant boundary conditions. The steady state results were used as initial conditions for the actual transient simulations to reduce the influence from inappropriate initial conditions. 


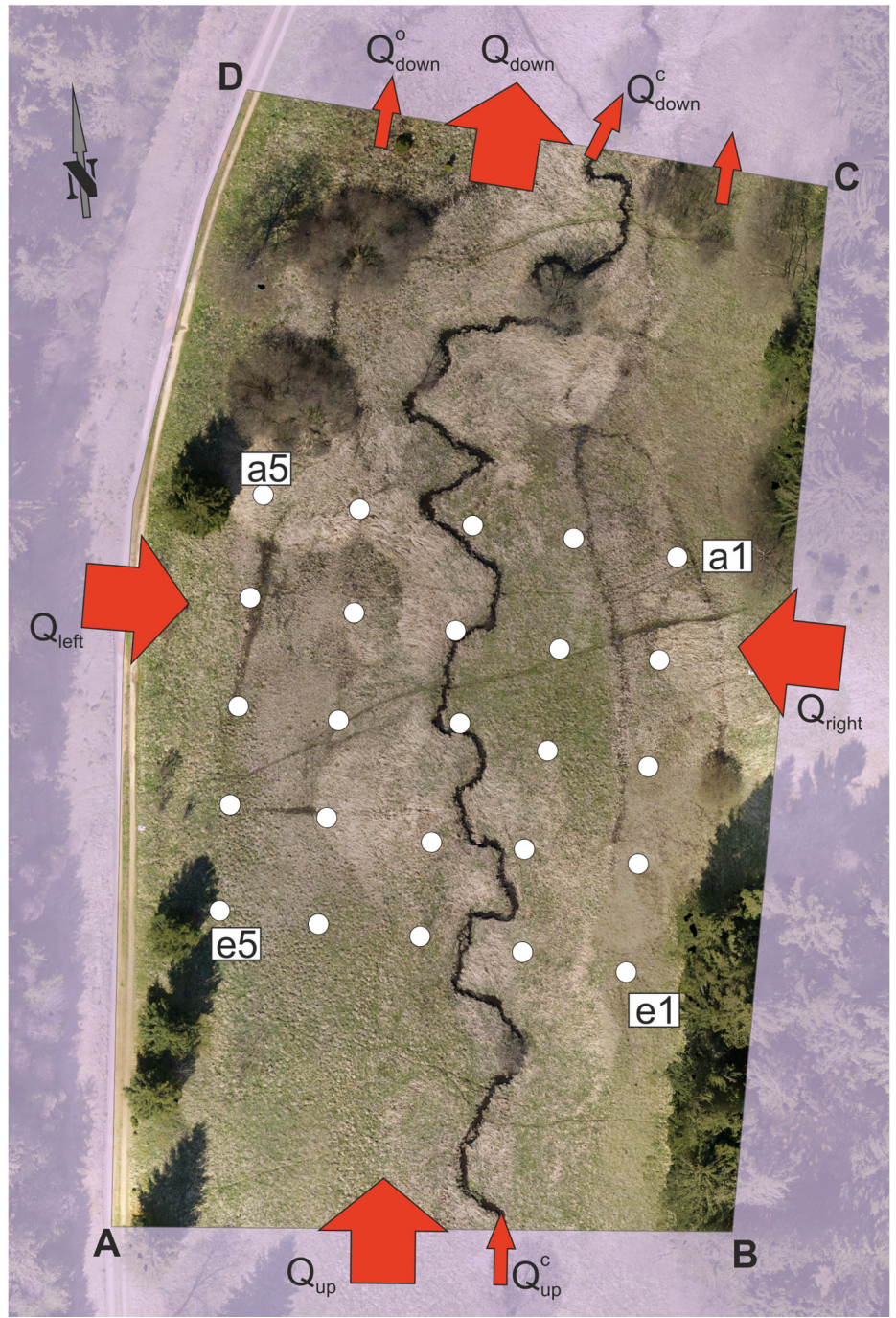

275 Figure 2. The boundary conditions of the study site (indicated by polygon A-D). $Q_{u p}$ : groundwater influx (const.), $Q_{u p}^{c}$ : channel influx (dynamic), $Q_{\text {down }}$ : groundwater leaving the model site (dynamic), $Q_{\text {down }}^{c}$ and $Q_{\text {down }}^{o}$ : surface water leaving the model site through channel outlet and through CD (dynamic), $Q_{\text {left }}$ and $Q_{\text {right }}$ : groundwater discharge rate from side boundaries (const.). Red arrows indicate flow direction of the water. The 25 white points indicate wells which were used for model calibration. Labels of the piezometer run from a to e (lines) and 1 to 5 (columns) respectively. 


\subsubsection{Calibration}

Transient calibration was performed using the software package PEST, which uses the Marquardt method to minimize a target function (describing the error between modeled and measured variables) by varying the values of a given set of parameters until the optimization criterion is reached (Doherty and Hunt, 2010). The calibrated model parameters (Table S2) were set to be adjustable within the selected ranges around their initial values. The measured groundwater level time-series at 25 observation wells and channel flux time-series at the outlet (similar location to $Q_{d o w n}^{c}$ ) were used to compare with the simulated ones (Fig. S5, such that the target function could be calculated. Because two different data sets (groundwater level and channel flux) were used, a weighting scheme was selected to let the defined multi-objective function be dominated by the data set of groundwater levels, because: (i) we focused more on the groundwater flow and the associated surface-subsurface exchange fluxes, and (ii) the channel flux was relatively easy to reproduce by the model as measured channel fluxes were directly assigned to the channel inlet. A period of 21 days from 15 November 2017 to 6 December 2017 was selected for the model calibration in view of the high CPU time demand for transient model runs and data availability constraints.

The time-variable groundwater levels were well replicated by the model for the wells near the channel (Fig. S2a). The wells close to channel had better fits than those near the side boundaries (Fig. S2b), because the latter were more strongly constrained by the constant groundwater fluxes through the side boundaries. The calibrated flow model was used to quantify internal water flux data from specific regions in the riparian zone. Additionally, advective-dispersive particle-tracking was used on the flow field from the calibrated model to visualize surface and subsurface flow paths through the model domain. The surface flow paths are used to identify key runoff generation zones in the riparian zone.

\subsection{Statistical methods}

Statistical analysis was performed using R (R-Core-Team, 2017). Evaluation of geospatial properties was conducted via R in combination with ArcMap (ESRI, US).

\subsubsection{Chemical classification of potential DOC source zones}

Peak intensity weighted average ( $w a$ ) of FT-ICR-MS derived molecular parameters (mass (mz), elemental ratios (H/C, O/C, $\mathrm{N} / \mathrm{C}, \mathrm{S} / \mathrm{C}$ ), nominal oxidation state of carbon (NOSC) and aromaticity index (AI)) was calculated for each sample by Eq. (1): $w a_{p}(x)=\frac{\sum p_{i}(x) \cdot \operatorname{int}_{i}(x)}{\sum \operatorname{int}_{i}(x)}$,

305 where $w a_{p}(x)$ is the weighted average value for the molecular parameter $p$ in sample $x . p_{i}(x)$ is the derived value for the parameter $p$ of each molecular formula $i$ in sample $x$. Accordingly, $\operatorname{int}_{i}(x)$ is the peak intensity for molecular formula $i$ in sample $x$.

A principal components analysis (PCA) was then performed with the RI of molecular formulas $(n=482)$ commonly detected in all riparian samples $(n=66)$ covering on average $40 \%$ of the assigned intensities in each sample. A consecutive k-means clustering on the first two principal components (R package FactoMineR (Lê et al., 2008)) was used to partition the riparian 
samples into two (as suggested by the silhouette index (Rousseeuw, 1987)) chemically distinct groups, representing different DOC quality in the riparian groundwater.

The Wilcoxon rank sum and the Kolmogorov Smirnov (KS) test were applied to identify significant differences in the distributions and medians of DOC concentration and FT-ICR-MS derived molecular parameters for the two groundwater DOC groups and stream water samples.

\subsubsection{Hydromorphological classification of potential DOC source zones}

Pearson correlation analysis was applied to every groundwater level time series with the stream water level time series. Geomorphological analysis was conducted via the TWI, according to Eq. (2)

$T W I=\log \left(\frac{f}{\tan (s)}\right)$,

320 Where TWI is the topographical wetness index for each cell, $f$ is the flow accumulation (the accumulated weight of all cells flowing into a downslope cell at the surface) at each cell and s is the slope in radians of respective triangular surface element. The DInf algorithm was used for calculating flow accumulation in ArcMap since it proved to depict more realistic hydrological routing (Tarboton, 1997). To account for mathematical infinity/indefinite terms, zero slopes were set to $0.001 \mathrm{rad}$, and cells with no flow accumulation $(f=0)$ were set to 1 cell instead.

325 A smoothed map of the local $\mathrm{TWI}_{\mathrm{HR}}$ values was created by assigning the median TWI value of the central cell and its 8 surrounding cells to the central cell. According to KS and F-test statistics, the resulting map represented the non-smoothened TWI distribution of the study site $\left(p_{\mathrm{KS}}=0.33 ; p_{\mathrm{F}}=0.76\right)$. We applied the Wilcoxon rank sum to test for differences in $\mathrm{TWI}_{\mathrm{HR}}$ distributions and medians of the two DOC clusters. For an extrapolation from point sources (i.e. sampled piezometers) to spatial entities, zones were demarcated that had higher $\mathrm{TWI}_{\mathrm{HR}}$ values than the median of the DOC cluster group of higher

$330 \mathrm{TWI}_{\mathrm{HR}}$. The water balance for the entire model site and the two TWI-generated zones was then estimated and compared to each other between 12 April 2017 and 19 December 2018 by modeling with HydroGeoSphere.

\section{Results}

\subsection{Hydroclimatic conditions and DOC chemical characterization}

The basic statistics of discharge, groundwater level and climatic variables throughout the 15 -months measurement period are

given in Table 1. Discharge shows event-type, erratic variability but in general followed a clear seasonal pattern, with lowest values in late summer and highest values in spring (Figure 3a). Stream water level was highest during a flood event from 01 to 03 January 2018 when the Rappbode stream went over-bank. We decided to not include this event in the statistics, because we could not estimate the discharge for water levels higher than the stream banks. Yet observing this flood event helped to verify and understand riparian surface runoff pathways at our study site. The amount of precipitation during 2018 (580 mm) 
340 was below the long-term annual mean $(831 \mathrm{~mm})$ at the nearest official weather station. Air temperature exhibited seasonal patterns and was above the long term annual mean at the nearest station $\left(8.6^{\circ} \mathrm{C}\right.$ vs. $\left.6.0^{\circ} \mathrm{C}\right)$.

Table 1: Basic climatic, hydrological and chemical statistics of the study site during the monitoring campaign between 12 April 2017 and 19 December 2018. ET: potential evapotranspiration, DOC conc.: DOC concentration, 'wa' indicates peak intensity weighted 345 average values of the subsequent DOC properties: $w a_{m z}$ (mass to charge ratio), waHC (hydrogen to carbon ratio), waoc (oxygen to carbon ratio), wasC (sulfur to carbon ratio), wa $\boldsymbol{w A}_{A I}$ (aromaticity index), wa $\mathrm{aSSC}_{\mathrm{N} C}$ (nominal oxidation state of carbon).

\begin{tabular}{ccccc}
\hline & mean & sd & $\min$ & $\max$ \\
\hline Air temperature $\left[{ }^{\circ} \mathrm{C}\right]$ & 8.6 & 8.18 & -18.9 & 34 \\
Rain $\left[\mathrm{mm} \mathrm{h}^{-1}\right]$ & 0.03 & 0.17 & 0 & 8.6 \\
$\mathrm{ET}_{0}\left[\mathrm{~mm} \mathrm{~d}^{-1}\right]$ & 1.59 & 2.7 & 0 & 13.8 \\
Stream water level $[\mathrm{cm}]$ & 14.64 & 8.48 & 3.54 & 69.94 \\
Discharge $\left[\mathrm{L} \mathrm{s}^{-1}\right]$ & 58.7 & 92.9 & 8.2 & 1116.0 \\
DOC conc. $\left[\mathrm{mg} \mathrm{L}^{-1}\right]^{1}$ & 3.80 & 2.77 & 0.69 & 15.77 \\
$w a_{m z}{ }^{1}$ & 435.8 & 7.65 & 420.3 & 452.53 \\
$w a_{H C}{ }^{1}$ & 1.28 & 0.05 & 1.15 & 1.41 \\
$w a_{O C}{ }^{1}$ & 0.4 & 0.01 & 0.36 & 0.45 \\
$w a_{S C}{ }^{1}$ & 0.01 & 0 & 0 & 0.02 \\
$w a_{A I}{ }^{1}$ & 0.09 & 0.02 & 0.05 & 0.15 \\
$w a_{N O S C}{ }^{1}$ & -0.41 & 0.06 & -0.55 & -0.16
\end{tabular}

${ }^{1}$ for 66 groundwater and riparian surface water samples taken from April 2018 to July 2019 (single spots were sampled multiple times throughout year)

350 Stream water levels (Figure 3c) were closely coupled with groundwater levels, with lower and more fluctuating water levels in summer and less variable, higher water levels in winter (Figure 3a). Water level fluctuations in wells closer to the stream followed stream stage variations more closely than in the wells more distant to the stream, which showed more damped dynamics. This results in Spearman correlations $\left(r_{\mathrm{s}}\right)$ of groundwater level time series with the stream between 0.43 and 0.86 (mean of all $r_{\mathrm{s}}=0.60$ ). The groundwater table was shallow throughout the measurement period with highest values in winter 355 and after snowmelt in spring (Figure $3 \mathrm{~b}$ ).

An overview of hydroclimatic data for the dates of DOC sampling (Figure 3b, c) in the stream or the RZ is given in Table S3. DOC concentrations in the stream during events generally followed the hydrograph, with higher concentrations during higher water levels. Although DOC concentration and molecular properties across all riparian groundwater samples exhibited variability (Table 1), DOC in riparian water samples was in general of highly unsaturated and phenolic composition, typically found in lignin and biomass type compounds. 


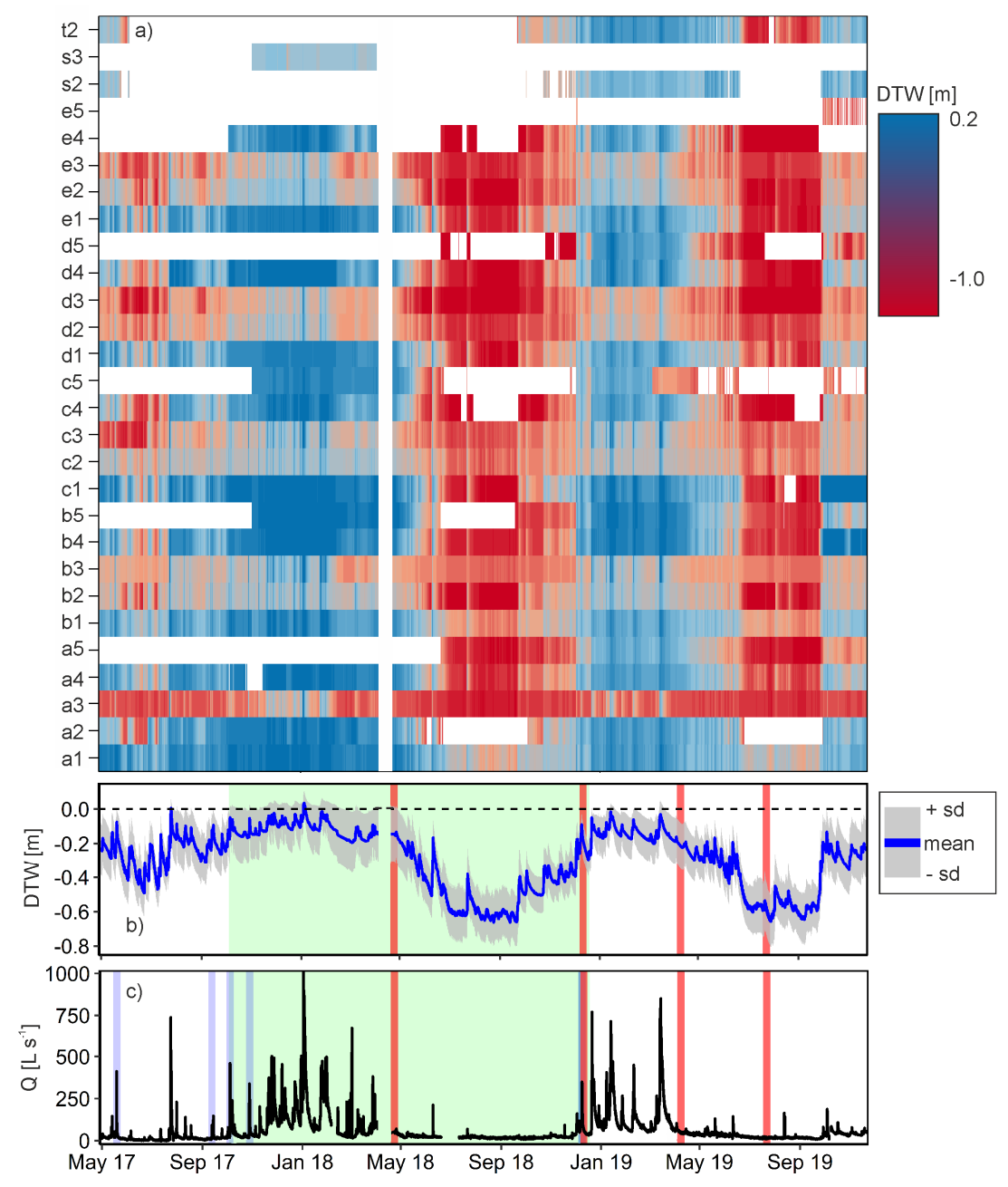

Figure 3. a) Depth to water table (DTW) time series of all 28 riparian wells. White spaces indicate missing data in the time series: due to varying (de)installation times (if white in the beginning), sensor failure (white gaps in every time series) and dryness induced (1) mean DTW values (blue line) \pm the standard deviation (grey ribbon). A positive value of DTW indicates water ponding at the soil surface or that the piezometer measured locally confined part of the aquifer. Red vertical lines indicate sampling dates of riparian groundwater. Green area indicates the modeling period where ground water levels were used for calibration. c) Discharge time series of the central pressure transducer. Blue vertical lines indicate stream water auto sampling dates during events, red vertical lines indicate sampling dates of stream water. Green area indicates the modeling period where ground water levels were used for calibration. Note that the flood event at the beginning of January 2018 is ungauged. 


\subsection{Classification and mapping of potential DOC sources}

\subsubsection{Chemical classification}

A detailed overview of the FT-ICR MS results of the distinct water samples can be found in S2, Table S5, and Figs. S9-S10. The PCA to classify riparian DOC quality was able to explain $66.3 \%$ of the total variance of DOC molecular peak intensities using 2 principal components (PCs). K-means clustering based on the PCs then separated the riparian samples into two groups of 19 and 47 samples $\left(\mathrm{DOC}_{\mathrm{I}}\right.$ and $\mathrm{DOC}_{\mathrm{II}}$, resp.; Fig. S6), representing distinct DOC quality in the riparian zone. Weighted average molecular parameters were significantly different between the two clusters, allowing for a clear separation between $\mathrm{DOC}_{\mathrm{I}}$ and $\mathrm{DOC}_{\mathrm{II}}$ (Figure 4a). Samples clustered in DOC $\mathrm{I}$ had higher DOC concentration and their molecular composition was

380 characterized by more oxidized (higher NOSC and $w a_{O C}$ ), more aromatic molecules (higher $w a_{A I}$ ), with a lower fraction of heteroatoms (smaller $w a_{S C}, w a_{N C}$ not shown), and a lower molecular weight (smaller $w a_{m z}$ ). Comparison of $\mathrm{DOC}_{\mathrm{I}}$ and $\mathrm{DOC}_{\mathrm{II}}$ molecular composition and concentration with that of stream water sampled during rain events in spring, summer and autumn confirmed overall different DOC quality distributions and medians between riparian groundwater and stream water (Fig. 4). However, median values of the $\mathrm{DOC}_{\mathrm{I}}$ cluster were always closer to the median of stream water event samples than the

385 respective $\mathrm{DOC}_{\mathrm{II}}$ median. Moreover, the DOC composition of one event in December (Fig. 4a, orange dots) was in the range of the riparian samples, but did not show much compositional variability within the event.

DOC $_{\mathrm{I}}$ samples from April $(n=9$, Fig. 3$)$ and December $(n=9)$ did not show significant differences in DOC molecular composition (except $w a_{H C}$ ) and concentration (Figure $4 \mathrm{~b}$ ). In addition, DOC concentration and quality in the stream samples (from the routine measurement program, non-event conditions) generally matched $\mathrm{DOC}_{\mathrm{I}}$ concentration and quality in April

390 and December (except $w a_{H C}$ and $\left.w a_{A I}\right)$. In contrast, DOC $\mathrm{II}_{\mathrm{II}}$ samples from April $(n=13)$ and December $(n=33)$ differed significantly according to their $w a_{m z}, w a_{H C}, w a_{A I}, w a_{N O S C}$ and DOC concentration (Figure $4 \mathrm{c}$ ). While DOC concentration and quality of stream water samples from December were mostly within the range of the respective $\mathrm{DOC}_{\mathrm{II}}$ samples, stream water samples from April were mostly outside the range of the DOC properties and concentrations of the respective DOC $_{\text {II }}$ samples. The cluster $\mathrm{DOC}_{\mathrm{I}}$ was associated with groundwater sampled at depth to water table (DTW) $>-0.3 \mathrm{~m}$ in 9 cases whereas the

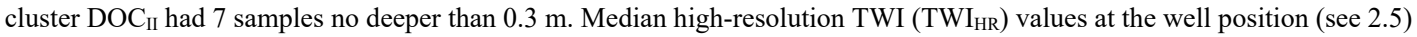
were grouped according to their attribution to the $\mathrm{DOC}_{\mathrm{I}}$ and $\mathrm{DOC}_{\mathrm{II}}$ clusters based on the chemical characterization. Note that 8 wells, sampled during different occasions throughout the year occur in both DOC clusters and according TWI $_{\mathrm{HR}}$ values can thus occur in both clusters (Fig. 4d). In general, the median values of $\mathrm{TWI}_{\mathrm{HR}}$ for $\mathrm{DOC}_{\mathrm{I}}$ wells were significantly higher (Wilcoxon rank sum $\mathrm{p}<0.008$ ) than respective values of the $\mathrm{DOC}_{\mathrm{II}}$ wells (Figure $4 \mathrm{~d}$ ). Both, distribution of $\mathrm{TWI}_{\mathrm{HR}}$ was different 400 and median was higher when comparing $\mathrm{DOC}_{\mathrm{I}} \mathrm{vs}_{\mathrm{DOC}} \mathrm{TWI}_{\mathrm{HR}}$ values from April, whereas December samples did not show any statistical significant difference in their $\mathrm{TWI}_{\mathrm{HR}}$ distribution or median. 

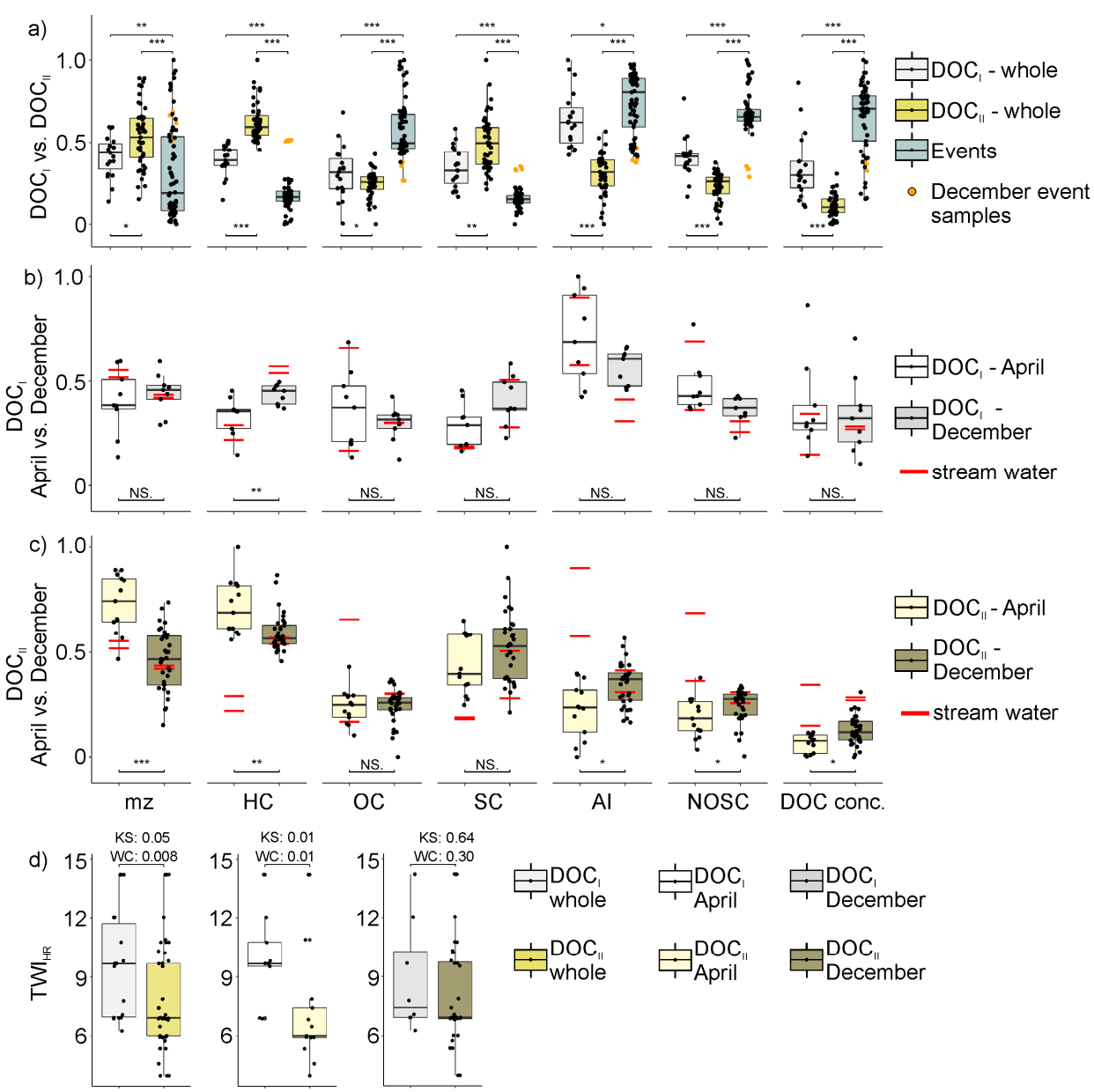

Figure 4. Comparison of FT-ICR-MS derived weighted average molecular parameters, DOC concentrations and high-resolution TWI (TWIHR) values of DOC I and DOC II samples. a) Boxplots of molecular parameters and DOC concentration of the DOC I $_{\text {and }}$



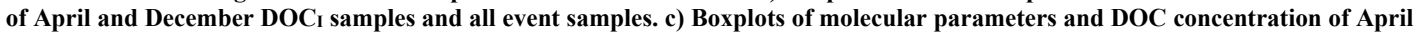
and December DOC II samples and all event samples. Red horizontal lines in b) and c) indicate weighted averages of two April and two December stream water samples collected during the respective riparian groundwater sampling campaign. Data in a) to c) were 410 min-max normalized to values between 0 and 1 for better illustration (see Table 1 for actual values). d) Boxplots of TWIHR values as affiliated to the respective wells of $D C_{I}$ and $D C_{I I}$ samples. Wilcoxon rank sum (WC) and Kolmogorov Smirnov (KS) test results are depicted above the squared brackets. Squared brackets above and below boxplots in a) to c) indicate the application of a KS test between two partitions. Asterisks indicate p-values of the KS test $(* * *:<0.001 ; * *:<0.01 ; *:<0.05$; NS: not significant). 


\subsubsection{Spatial mapping}

415 The significant difference in $\mathrm{TWI}_{\mathrm{HR}}$ median values of $\mathrm{DOC}_{\mathrm{I}}$ and $\mathrm{DOC}_{\mathrm{II}}$ wells (Wilcoxon rank sum $p<0.008$ ) was used to spatially separate both potential source zones from each other by using the median $\mathrm{TWI}_{\mathrm{HR}}$ value of the $\mathrm{DOC}_{\mathrm{I}}$ group (9.66) as a threshold. Overall, this TWI threshold also includes $25 \%$ of the samples from the $\mathrm{DOC}_{\text {II }}$ group. However, this percentage dropped to $15 \%$ in April. Also note that different samples of one well can appear in both DOC groups. This $\mathrm{TWI}_{\mathrm{HR}}$ classification split the riparian zone into zones of high $\mathrm{TWI}_{\mathrm{HR}}\left(\mathrm{DOC}_{\mathrm{I}}\right.$ source zone) and low $\mathrm{TWI}_{\mathrm{HR}}\left(\mathrm{DOC}_{\mathrm{II}}\right.$ source zone) values (Figure 5). The high TWI $_{H R}$ zones defined in this way made up $14.6 \%$ of the study site. The HydroGeoSphere (HGS) model was then used to quantify the runoff generation from the delineated $\mathrm{DOC}_{\mathrm{I}}$ source zones and to quantify their impact on total runoff generation and DOC export from the study site. According to our simulations surficial runoff (that is groundwater discharging to the surface or direct precipitation onto saturated areas feeding the stream) was the main contribution to overall runoff generation at the site (Figure 6). The median contribution of surficial runoff to total runoff generation was $61 \%$ ( \pm 12 $\%$ standard deviation) but surface contributions increased up to $99 \%$ during event situations. We selected the subsurfacesurface exchange flux as a key descriptive variable for potential surface runoff contributions, because it quantifies the availability of water at the surface for each cell of the model. Although there was a 1.5 times higher net surface water flux generation from low $\mathrm{TWI}_{\mathrm{HR}}$ zones throughout the modeling period (Figure 6b), the median of the area-normalized water exchange flux for high TWI $\mathrm{HR}_{\mathrm{HR}}$ zones $\left(0.026 \mathrm{~m} \mathrm{~d}^{-1}\right)$ was about 8.6 times higher than that for $\mathrm{DOC}_{\mathrm{II}}$ source zones $\left(0.003 \mathrm{~m} \mathrm{~d}^{-1}\right)$. This resulted in higher absolute exchange fluxes in high $\mathrm{TWI}_{\mathrm{HR}}$ zones in about $47 \%$ of the modeling period. During (nonwinter) runoff events, water exchange flux contribution of high $\mathrm{TWI}_{\mathrm{HR}}$ zones increased up to $100 \%$ (negative or no exchange flux for $\mathrm{DOC}_{\mathrm{II}}$ source zones in dry summer) whereas low $\mathrm{TWI}_{\mathrm{HR}}$ zones contributed more potential surface runoff at non-event winter conditions and flooding events when high overall exchange fluxes occurred under fully saturated soil conditions. Hydrological conditions were exemplary mapped for situations on 13 December 2017, immediately after an event under wet conditions, and on 29 August 2018, amidst a prolonged dry period in summer (Fig. S7, Table S4 for according water fluxes). High $\mathrm{TWI}_{\mathrm{HR}}$ zones had the highest exchange fluxes and water depths in both wet and dry situations. Surface flow paths in winter intersect the high $\mathrm{TWI}_{\mathrm{HR}}$ zones establishing hydrologic connectivity between these zones and the stream, which is in line with our observations on DOC quality. The highest positive exchange flux values (GW exfiltration) occurred at the outer hillslope boundaries of the RZ, running parallel to the channel (values at the exact boundaries of the model have not been taken into account due to potential boundary effects). These exfiltration spots were located close to the strongest surface water infiltration spots. During the exemplary wet situation, the entire RZ was saturated with water besides the stream banks. Surficial runoff pathways then connect the $\mathrm{DOC}_{\mathrm{I}}$ source areas (high $\mathrm{TWI}_{\mathrm{HR}}$ zones), running parallel to the stream and eventually entering it within the modeled domain. 


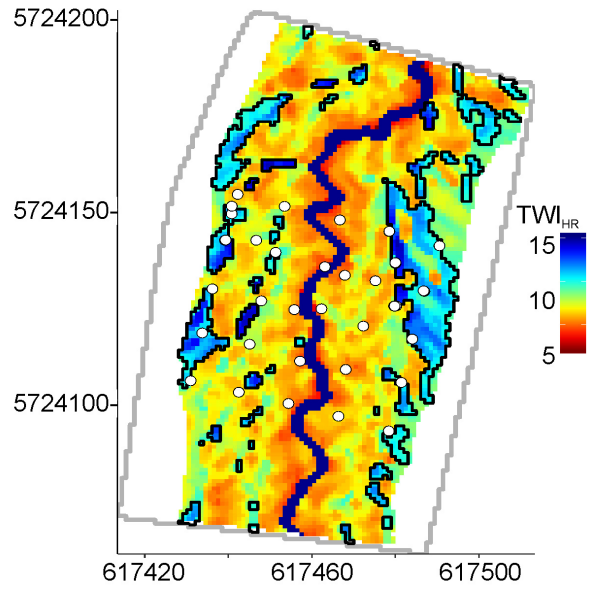

Figure 5. High resolution TWI (TWI $\mathrm{HR}_{\mathrm{H}}$ ) map of the modeled site (excluding hillslopes). White points indicate sampling locations, the Rappbode stream is indicated by the blue line. Black polygons are high $\mathrm{TWI}_{\mathrm{HR}}$ zones, indicating $\mathrm{DOC}_{\mathrm{I}}$ source areas.

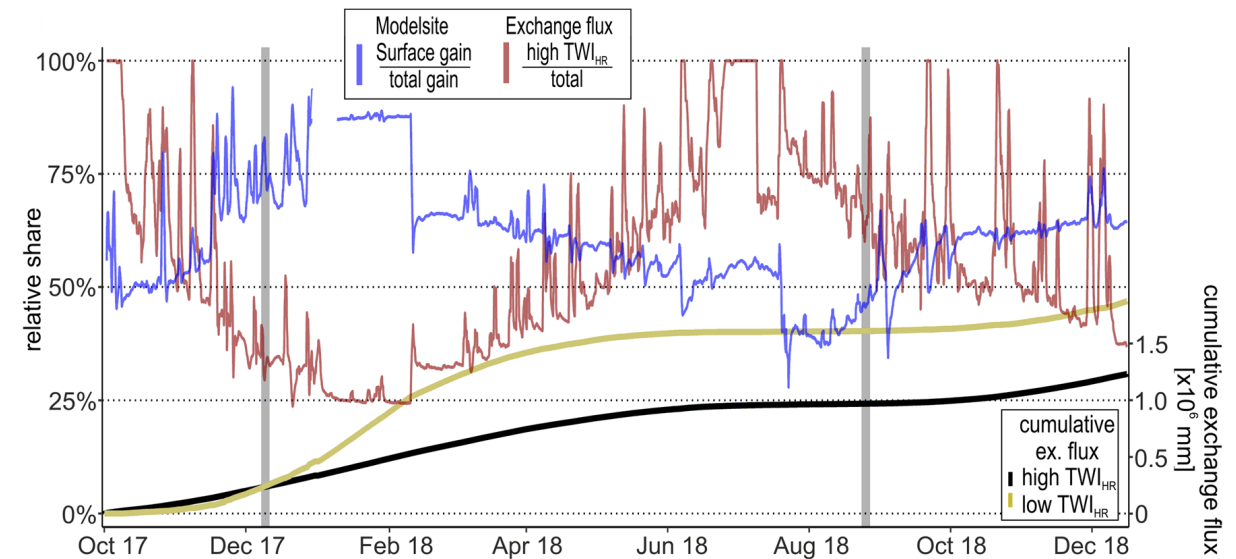

Figure 6. Share of surface runoff on total runoff generation (blue line) and of high-TWIHR zone water exchange flux on total exchange flux in the model site (red). Data was smoothed to daily values for better visualization. The gap in the blue graph in January 2018 is due to an ungauged flood event. Cumulative positive water exchange flux of high TWIHR (black) and low TWIHR (yellow/khaki) source zones shown on second $y$ axis. Grey bars indicate modeling dates for a wet situation on 13 December 2017 , right after an event and at dry conditions and on 29 August 2018, amidst of a longer dry period in summer. 


\subsection{Surface DOC export from high $\mathrm{TWI}_{\mathrm{HR}}$ and low $\mathrm{TWI} \mathrm{I}_{\mathrm{HR}}$ source zones}

During the model period, $\mathrm{DOC}_{\mathrm{I}}$ source wells had a median DOC concentration of $5.8 \mathrm{mg} \mathrm{L}^{-1}$ which was 2.3 times higher than for the $\mathrm{DOC}_{\mathrm{II}}$ source wells. We assumed the DOC concentrations to stay in a range of mean $\pm \mathrm{SD}$ throughout the year (cf. Figure $4 \mathrm{~b}, \mathrm{c}$ ). DOC export was then roughly calculated by multiplying mean $\pm \mathrm{SD}$ of $\mathrm{DOC}_{\mathrm{I}}$ and $\mathrm{DOC}_{\mathrm{II}}$ concentrations with the absolute surface runoff volumes from the respective high and low $\mathrm{TWI}_{\mathrm{HR}}$ zones. With that mean overall export from high $\mathrm{TWI}_{\mathrm{HR}}$ zones exceeded that from low $\mathrm{TWI}_{\mathrm{HR}}$ zones in about $70 \%$ of the time although making up only $14.6 \%$ of the total area. In absolute numbers, high $\mathrm{TWI}_{\mathrm{HR}}$ zones exported roughly 1.5 times the amount of DOC $\left(7.1 \cdot 10^{6} \mathrm{~g}\right)$ to the stream than low $\mathrm{TWI}_{\mathrm{HR}}$ zones $\left(4.6 \cdot 10^{6} \mathrm{~g}\right)$. This amounts to a nearly 20 times higher area-normalized DOC export from high $\mathrm{TWI}_{\mathrm{HR}}$ zones than from low $\mathrm{TWI}_{\mathrm{HR}}$ zones. Highest disparity between the export of the two source zones was during events in autumn and spring when water in the low $\mathrm{TWI}_{\mathrm{HR}}$ zone infiltrated rather into the ground (no DOC export from low $\mathrm{TWI}_{\mathrm{HR}}$ zones, Figure 7) while high $\mathrm{TWI}_{\mathrm{HR}}$ zones exported DOC (positive spikes). Infiltrating conditions for the high $\mathrm{TWI}_{\mathrm{HR}}$ zone only occurred during summer events when DOC export was generally at the minimum (mean daily export rates of 3.1 and $17.3 \mathrm{~g} \mathrm{~d}^{-1}$ for low and high $\mathrm{TWI}_{\mathrm{HR}}$ zones, respectively) whereas equally high DOC export occurred in winter $\left(234.2 \mathrm{~g} \mathrm{~d}^{-1}\right.$ and $267.2 \mathrm{~g} \mathrm{~d}^{-1}$ for low and high $\mathrm{TWI}_{\mathrm{HR}}$ zones, respectively). The median export from the high $\mathrm{TWI}_{\mathrm{HR}}$ zone was above that from low $\mathrm{TWI}_{\mathrm{HR}}$ zone in nonwinter conditions, with the highest disparity between medians in spring and autumn (Figure 7). Then high $\mathrm{TWI}_{\mathrm{HR}}$ zones exhibited exfiltrating conditions, whereas water in low $\mathrm{TWI}_{\mathrm{HR}}$ zones kept infiltrating.

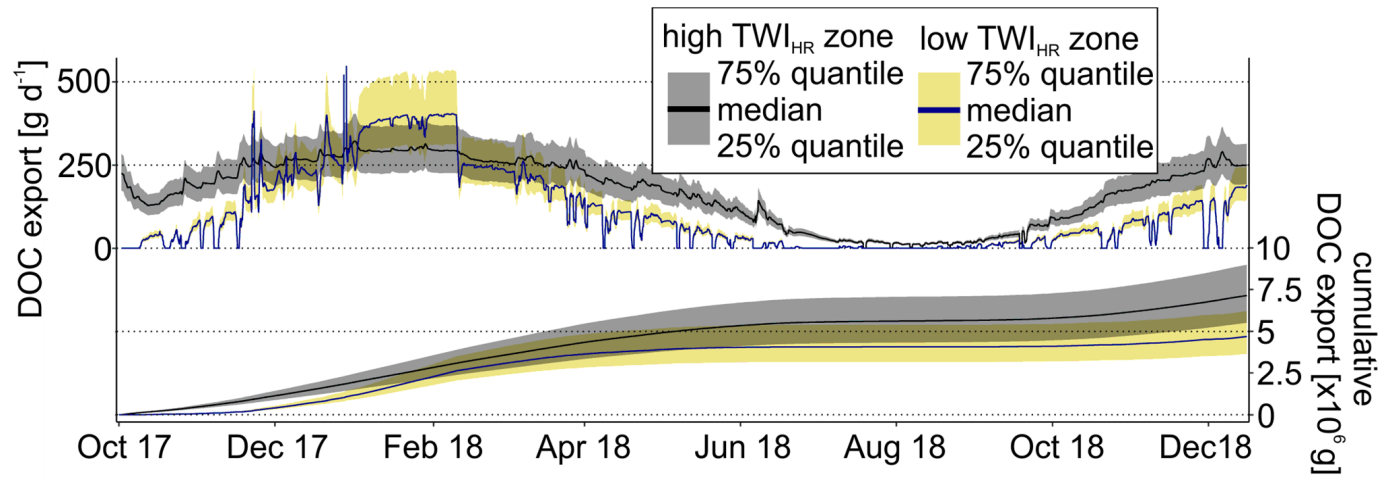

470 Figure 7. Absolute DOC surface export (25, 50 and 75 percentiles) from high (DOC I quality) and low (DOC II quality) TWIHR source zones. Underlying DOC concentration percentiles based on all riparian groundwater samples of each source zone. Cumulative positive DOC export $\left(25,50\right.$ and 75 percentiles) from high and low $T W I_{H R}$ zones shown on the second $y$ axis. 


\section{Discussion}

\subsection{Chemical and hydrological classification of riparian DOC source zones}

We chemically classified riparian groundwater samples with regards to DOC composition throughout the year and compared them to the DOC composition in event- and base-flow stream water in order to detect dominant riparian DOC source zones during different hydrological conditions. Clustering the riparian samples revealed two distinct DOC pools in the RZ (DOC and $\mathrm{DOC}_{\mathrm{II}}$ ), differing in their concentrations and molecular characteristics, thus representing different biogeochemical and physicochemical settings within the RZ. The $\mathrm{DOC}_{\mathrm{I}}$ pool reflects processed plant-derived organic matter with low bioavailability (higher degree of aromatic, oxidized compounds, low fraction of heteroatoms). The molecular character of the $\mathrm{DOC}_{\mathrm{I}}$ indicates low organic matter turnover presumably due to oxygen limitation even in the topmost soil layers, similar to typical wetland sites (Tfaily et al., 2018). Accordingly, $\mathrm{DOC}_{\mathrm{I}}$ source zones are connected to constantly low DTW values and high $\mathrm{TWI}_{\mathrm{HR}}$ values indicating waterlogging. In turn this may explain the conservation of $\mathrm{DOC}_{\mathrm{I}}$ due to anaerobic conditions (LaCroix et al., 2019). In contrast, the $\mathrm{DOC}_{\mathrm{II}}$ quality can be attributed to increased microbial processing of organic matter from organic rich top-soil layers. Matching our observations, the $\mathrm{DOC}_{\mathrm{II}}$ compounds are generally characterized by microbial, secondary metabolites (aliphatic, heteroatom enriched molecules) and DOC which is not adsorbed to mineral phases (small, low aromatic and oxygen depleted molecules) as typically found in deeper soil layers (Shen et al., 2015; Kaiser and Kalbitz, 2012; LaCroix et al., 2019).

The close agreement between $\mathrm{DOC}_{\mathrm{I}}$ characteristics and according stream water samples in April and December indicates a predominant connectivity of the $\mathrm{DOC}_{\mathrm{I}}$ pool with the stream during wet conditions and high groundwater levels. Here the $\mathrm{DOC}_{\mathrm{I}}$ quality did not show significant differences between April and December indicating a replete DOC pool with constant contribution to the overall DOC quality in the stream. In contrast, the $\mathrm{DOC}_{\mathrm{II}}$ composition was reflected in the stream water composition in December but not in April, indicating the influence of seasonality on this pool. Less organic matter input and lower biogeochemical process rates in winter and at the same time increased DOC export (at higher groundwater levels) may specifically deplete the $\mathrm{DOC}_{\text {II }}$ pool (Werner et al., 2019). The composition of $\mathrm{DOC}_{\text {II }}$ samples in April thus may represent a pool of DOC of low solubility with low sorption affinity which was not depleted during high groundwater levels in winter (saturated and with larger molecular weight).

Variations in stream DOC composition also appeared at the shorter event time scale. Fully saturated riparian conditions caused hydrological mixing of the $\mathrm{DOC}_{\mathrm{I}}$ and $\mathrm{DOC}_{\mathrm{II}}$ pool in December, leading to a stream DOC signal that was in-between the two riparian DOC pools. On the other hand, $\mathrm{DOC}_{\mathrm{I}}$ and stream water $\mathrm{DOC}$ compositions are converging during events at nonsaturated soil conditions. Consequently, changing source contributions from both riparian DOC pools are induced by the prevailing hydrological situation and therefore have to be considered as a general mechanism of DOC export in the catchment. Observed shifts between distributions of stream and riparian DOC composition might be due to near- and instream processing (Dawson et al., 2001; Battin et al., 2003), but also inter- and intra-annual variability of hydroclimatic drivers like seasonality or antecedent soil conditions (Werner et al., 2019; Köhler et al., 2009; Strohmeier et al., 2013; Futter and de Wit, 2008). Yet 
we showed direct links between six major DOC molecular properties and the DOC concentration of riparian and stream water samples. In comparison to other studies, which use integrated or indirect signals to derive information on DOC characteristics, like (specific) UV absorption and spectrophotometric slopes values (Ledesma et al., 2018b; Werner et al., 2019), or conductivity and $\mathrm{pH}$ (Ploum et al., 2020), this allows a spatial explicit alignment of riparian DOC sources zones to stream water samples at high credibility.

\subsection{Hydrologic controls and quantification of riparian DOC export}

Additionally, the physically-based model HGS independently shows that the dominant runoff generating mechanism (and thus potential DOC export pathway) at the study site is surface runoff from $\mathrm{DOC}_{\mathrm{I}}$ source zones, because respective high $\mathrm{TWI}_{\mathrm{HR}}$ zones have a different hydrological setting that produces more runoff per unit area and reacts more direct to precipitation than $\mathrm{DOC}_{\mathrm{II}}$ source zones (with low $\mathrm{TWI}_{\mathrm{HR}}$ values). A first estimation reveals an overall dominance of $\mathrm{DOC}_{\mathrm{I}}$ export from high $\mathrm{TWI}_{\mathrm{HR}}$ zones during events, despite making up only about $15 \%$ of the total study site. Consequently, DOC can be regarded as a site specific multi-facetted tracer that can provide a deeper insight into hydrologically controlled contributions of variable source zones: The whole RZ contributes rather uniformly to surficial DOC export during fully saturated soil conditions (e.g. during winter - as long as there is enough DOC available for transport) suggesting equal contributions from $\mathrm{DOC}_{\mathrm{I}}$ and $\mathrm{DOC}_{\mathrm{II}}$ source zones. Here a median large scale TWI will be enough to describe DOC export. In contrast, there is no surficial DOC export during dry situations. However in-between those two extremes, event-induced surficial DOC export is a function of soil wetness which regulates biogeochemical DOC processing and potential hydrological surface export (Werner et al., 2019). During such intermediate event situations, surface DOC export from high $\mathrm{TWI}_{\mathrm{HR}}$ zones increases whereas low $\mathrm{TWI}_{\mathrm{HR}}$ zones still depict zero surface export and stream water will shift to a $\mathrm{DOC}_{\mathrm{I}}$ dominated composition.

\subsection{Implications for DOC export modeling}

Recent studies conclude that lateral DOC export is not well researched, but is an important component of the global DOC budget (Zarnetske et al., 2018; Wen et al., 2020). In this regard, we found that surficial DOC export dominated overall lateral DOC export in our study site. Yet surface DOC export is underrepresented in current model-conceptualizations of lateral DOC export (Dick et al., 2015; Ledesma et al., 2018a; Bracken et al., 2013; Ploum et al., 2020). Reasons for the exclusion might be due to the high complexity of representing the spatio-temporal heterogeneity of surface export in modeling concepts or just because it does not play an important role in other catchments. With this study on $\mathrm{TWI}_{\mathrm{HR}}$, we present a proxy of small scale heterogeneities in surface runoff generation and respective DOC export that bears the potential to improve existing DOC export models and could lead to new approaches and concepts for better DOC export modeling. Adding a $\mathrm{TWI}_{\mathrm{HR}}$ based dynamic source zone activation term could greatly improve the mechanistic basis of lumped, parsimonious models potentially leading

535 to a more accurate upscaling of DOC export from RZs, especially for RZs with minimal slopes that tend to have highest groundwater levels and thus surface runoff. A general, coarse-scale relationship between soil moisture and potential surface runoff generation has already been proposed based on a catchment-scale topography-driven runoff proxy (Gao et al., 2019, 
Birkel et al., 2020). The mechanistic connection between TWI and surface DOC export in our study represents a similar general mechanism that is applicable for the whole riparian zone in small catchments (similar $\mathrm{TWI}_{\mathrm{HR}}$ values should result in similar runoff generation). In contrast, small scale topographical proxies of DOC export based on the presented $\mathrm{TWI}_{\mathrm{HR}}$ have the potential to more accurately represent distinct zones of DOC export during differing hydrological situations. Then weather data can subsequently be used to estimate which distinct source zones (hot spots) contribute to DOC export during a precipitation event (hot moment), thus overcoming the restrictive dichotomy of the hot-spot hot-moment concept (Bernhardt et al., 2017).

\section{Conclusions}

Chemical classification of riparian groundwater samples via ultra-high resolution FT-ICR-MS revealed two distinct DOC pools $\left(\mathrm{DOC}_{\mathrm{I}}\right.$ and $\left.\mathrm{DOC}_{\mathrm{II}}\right)$ in the riparian zone. Degrading plant material presumably contributes most to an aromatic, oxygenrich DOC pool with high concentrations, located in regions of high wetness and local topographic depressions. This DOC pool tends to be available for microbial degradation (Mostovaya et al., 2017), can be photodegraded (Wilske et al., 2020), and

550 can be relatively easily removed through sedimentation (Dadi et al., 2017) or during drinking water treatment (Raeke et al., 2017). However, it also has a potential for disinfection byproduct formation (Wang et al., 2017) when not removed sufficiently. The second pool $\left(\mathrm{DOC}_{\mathrm{II}}\right)$ reflects microbially processed, mobile DOC with lower concentration and larger compositional variability across seasons. Respective source zones of $\mathrm{DOC}_{\mathrm{I}}$ and $\mathrm{DOC}_{\mathrm{II}}$ can be separated and mapped by a threshold value in high-resolution TWI $\left(\mathrm{TWI}_{\mathrm{HR}}\right.$ ). The identification of source zones was achieved via independent measures (unsupervised chemical classification, and TWI-based physical flux modeling) indicating high credibility. Additionally, hydrological modeling revealed that the dominant runoff generation mechanism in the study site was surface runoff. Here $\mathrm{DOC}_{\mathrm{I}}$ source zones, which make up $15 \%$ of the total study site provided 1.5 times more DOC for export than the remaining $85 \%$ of the area associated with the $\mathrm{DOC}_{\text {II }}$ pool. Furthermore, highest discrepancy between the $\mathrm{DOC}_{\mathrm{I}}$ and $\mathrm{DOC}_{\mathrm{II}}$ surface export was during events at intermediate wetness states (neither completely saturated nor very dry). Overall, this is a strong indication that $\mathrm{DOC}_{\mathrm{I}}$ sources rather than $\mathrm{DOC}_{\mathrm{II}}$ sources get exported into the stream during event situations. We therefore conclude that certain thresholds in $\mathrm{TWI}_{\mathrm{HR}}$, which are based on actual wetness state, can identify explicit source zones of surficial DOC export from riparian zones. Thus $\mathrm{TWI}_{\mathrm{HR}}$ in turn defines the relative contributions from different source zones with more unique DOC source signals in the stream during dry and transitional periods whereas mixed signals occur during very wet conditions. In contrast to other studies in northern till catchments (e.g. Ledesma et al. (2018b)), this study highlights that surface DOC export from the riparian zone plays an important role for lateral DOC export from hydromorphic soils with overall low topographic relief. Therefore we want to emphasize that surface export should be acknowledged in respective DOC export models. Delineating activated source zones for DOC export by topographic proxies of lateral, spatial heterogeneity (here represented by $\mathrm{TWI}_{\mathrm{HR}}$ ) can help to identify source zones in existing DOC models or provide a mechanistic basis for improved model conceptualization for lateral DOC export modeling. 
Supplement. The supplement related to this article is available online at:

Author contributions. BJW, JHF, OJL, AM and GHdR planned and designed the research. BJW performed the statistical analysis and wrote the paper with contributions from all co-authors. JY edited the hydrological modelling. UW implemented geophysical investigations. RG provided post-processed drone altimetry data.

Competing interests. Gerrit de Rooij is a member of the editorial board of the journal.

Acknowledgements. Jan M. Kaesler is gratefully acknowledged for the FT-ICR-MS analysis at the Centre for Chemical Microscopy (ProVIS) at the Helmholtz Centre for Environmental Research, which is supported by the European Regional

580 Development Funds (EFRE-Europe funds Saxony) and the Helmholtz Association. We thank Toralf Keller for excellent and steady field work, Marco Pohle for geophysical field work, Kai Franze for software development and Heidrun Paschke and Michaela Wunderlich for help with the DOC and nutrient analysis.

Financial support. This research was funded by the Helmholtz Research Program POF-III, Integrated Project "Water and Matter Flux Dynamics in Catchments".

\section{References}

Allen, R. G., Pereira, L. S., Raes, D., and Smith, M.: Crop evapotranspiration. Guidelines for computing crop water requirements. , Irrigation and Drainage, edited by: FAO, FAO, Rome, 1998.

Andersson, J. O., and Nyberg, L.: Using official map data on topography, wetlands and vegetation cover for prediction of stream water chemistry in boreal headwater catchments, Hydrology and Earth System Sciences, 13, 537-549, DOI 10.5194/hess-13-537-2009, 2009.

590 Battin, T. J., Kaplan, L. A., Newbold, J. D., and Hendricks, S. P.: A mixing model analysis of stream solute dynamics and the contribution of a hyporheic zone to ecosystem function, Freshwater Biology, 48, 995-1014, 10.1046/j.1365-2427.2003.01062.x, 2003.

Battin, T. J., Kaplan, L. A., Findlay, S., Hopkinson, C. S., Marti, E., Packman, A. I., Newbold, J. D., and Sabater, F.: Biophysical controls on organic carbon fluxes in fluvial networks, Nature Geoscience, 1, 95-100, 10.1038/ngeo101, 2008.

595 Bernhardt, E. S., Blaszczak, J. R., Ficken, C. D., Fork, M. L., Kaiser, K. E., and Seybold, E. C.: Control Point

Beven, K. J., and Kirkby, M. J.: A physically based, variable contributing area model of basin hydrology, Hydrological Sciences Journal, 24, 43-69, 10.1080/02626667909491834, 1979.

Birkel, C., Duvert, C., Correa, A., Munksgaard, N. C., Maher, D. T., and Hutley, L. B.: Tracer-Aided Modeling in the Low-Relief, Wet-Dry Tropics Suggests Water Ages and DOC Export Are Driven by Seasonal Wetlands and Deep Groundwater, Water Resources Research, 56, e2019WR026175, 10.1029/2019WR026175, 2020

Bishop, K., Seibert, J., Koher, S., and Laudon, H.: Resolving the Double Paradox of rapidly mobilized old water with highly variable responses in runoff chemistry, Hydrological Processes, 18, 185-189, 10.1002/hyp.5209, 2004.

Bracken, L. J., Wainwright, J., Ali, G. A., Tetzlaff, D., Smith, M. W., Reaney, S. M., and Roy, A. G.: Concepts of hydrological connectivity: Research approaches, pathways and future agendas, Earth-Science Reviews, 119, 17-34, 10.1016/j.earscirev.2013.02.001, 2013.

605 Chantigny, M. H.: Dissolved and water-extractable organic matter in soils: a review on the influence of land use and management practices, Geoderma, 113, 357-380, 10.1016/S0016-7061(02)00370-1, 2003.

Cole, J. J., Prairie, Y. T., Caraco, N. F., McDowell, W. H., Tranvik, L. J., Striegl, R. G., Duarte, C. M., Kortelainen, P., Downing, J. A., Middelburg, J. J., and Melack, J.: Plumbing the global carbon cycle: Integrating inland waters into the terrestrial carbon budget, Ecosystems, 10, 171-184, 10.1007/s10021-006-9013-8, 2007.

610 Dadi, T., Harir, M., Hertkorn, N., Koschorreck, M., Schmitt-Kopplin, P., and Herzsprung, P.: Redox Conditions Affect Dissolved Organic Carbon Quality in Stratified Freshwaters, Environ Sci Technol, 51, 13705-13713, 10.1021/acs.est.7b04194, 2017. 
Dawson, J. J. C., Bakewell, C., and Billett, M. F.: Is in-stream processing an important control on spatial changes in carbon fluxes in headwater catchments?, Science of The Total Environment, 265, 153-167, 10.1016/s0048-9697(00)00656-2, 2001.

Detty, J. M., and McGuire, K. J.: Threshold changes in storm runoff generation at a till-mantled headwater catchment, Water Resources Research, 46, 10.1029/2009wr008102, 2010.

Dick, J. J., Tetzlaff, D., Birkel, C., and Soulsby, C.: Modelling landscape controls on dissolved organic carbon sources and fluxes to streams, Biogeochemistry, 122, 361-374, 10.1007/s10533-014-0046-3, 2015.

Dittmar, T., Koch, B., Hertkorn, N., and Kattner, G.: A simple and efficient method for the solid-phase extraction of dissolved organic matter (SPE-DOM) from seawater, Limnology and Oceanography-Methods, 6, 230-235, 10.4319/lom.2008.6.230, 2008.

620 Doherty, J. E., and Hunt, R. J.: Approaches to highly parameterized inversion: a guide to using PEST for groundwater-model calibration, US Department of the Interior, US Geological Survey, 2010.

Duncan, J. M., Groffman, P. M., and Band, L. E.: Towards closing the watershed nitrogen budget: Spatial and temporal scaling of denitrification, Journal of Geophysical Research-Biogeosciences, 118, 1105-1119, 10.1002/jgrg.20090, 2013.

Fellman, J. B., Buma, B., Hood, E., Edwards, R. T., and D'Amore, D. V.: Linking LiDAR with streamwater biogeochemistry in coastal temperate rainforest watersheds, Canadian Journal of Fisheries and Aquatic Sciences, 74, 801-811, 10.1139/cjfas-2016-0130, 2017.

Frei, S., Lischeid, G., and Fleckenstein, J. H.: Effects of micro-topography on surface-subsurface exchange and runoff generation in a virtual riparian wetland - A modeling study, Advances in Water Resources, 33, 1388-1401, 10.1016/j.advwatres.2010.07.006, 2010.

Frei, S., Knorr, K. H., Peiffer, S., and Fleckenstein, J. H.: Surface micro-topography causes hot spots of biogeochemical activity in wetland systems: A virtual modeling experiment, Journal of Geophysical Research-Biogeosciences, 117, n/a-n/a, 10.1029/2012jg002012, 2012.

630 Futter, M. N., and de Wit, H. A.: Testing seasonal and long-term controls of streamwater DOC using empirical and process-based models, Sci Total Environ, 407, 698-707, 10.1016/j.scitotenv.2008.10.002, 2008.

Gao, H. K., Birkel, C., Hrachowitz, M., Tetzlaff, D., Soulsby, C., and Savenije, H. H. G.: A simple topography-driven and calibration-free runoff generation module, Hydrology and Earth System Sciences, 23, 787-809, 10.5194/hess-23-787-2019, 2019.

Grabs, T., Bishop, K., Laudon, H., Lyon, S. W., and Seibert, J.: Riparian zone hydrology and soil water total organic carbon (TOC): implications for spatial variability and upscaling of lateral riparian TOC exports, Biogeosciences, 9, 3901-3916, 10.5194/bg-9-3901$2012,2012$.

Herzsprung, P., Hertkorn, N., von Tümpling, W., Harir, M., Friese, K., and Schmitt-Kopplin, P.: Understanding molecular formula assignment of Fourier transform ion cyclotron resonance mass spectrometry data of natural organic matter from a chemical point of view, Anal Bioanal Chem, 406, 7977-7987, 10.1007/s00216-014-8249-y, 2014.

640 Herzsprung, P., Wentzky, V., Kamjunke, N., von Tümpling, W., Wilske, C., Friese, K., Boehrer, B., Reemtsma, T., Rinke, K., and Lechtenfeld, O. J.: Improved Understanding of Dissolved Organic Matter Processing in Freshwater Using Complementary Experimental and Machine Learning Approaches, Environmental Science \& Technology, 10.1021/acs.est.0c02383, 2020.

Inamdar, S. P., and Mitchell, M. J.: Hydrologic and topographic controls on storm-event exports of dissolved organic carbon (DOC) and nitrate across catchment scales, Water Resources Research, 42, 10.1029/2005wr004212, 2006

645 Kaiser, K., and Kalbitz, K.: Cycling downwards - dissolved organic matter in soils, Soil Biology \& Biochemistry, 52, 29-32, 10.1016/j.soilbio.2012.04.002, 2012

Kind, T., and Fiehn, O.: Seven Golden Rules for heuristic filtering of molecular formulas obtained by accurate mass spectrometry, BMC Bioinformatics, 8, 105-105, 10.1186/1471-2105-8-105, 2007.

Koch, B. P., Kattner, G., Witt, M., and Passow, U.: Molecular insights into the microbial formation of marine dissolved organic matter: recalcitrant or labile?, Biogeosciences, 11, 4173-4190, 10.5194/bg-11-4173-2014, 2014.

Köhler, S. J., Buffam, I., Seibert, J., Bishop, K. H., and Laudon, H.: Dynamics of stream water TOC concentrations in a boreal headwater catchment: Controlling factors and implications for climate scenarios, Journal of Hydrology, 373, 44-56, 10.1016/j.jhydrol.2009.04.012, 2009.

Krause, S., Freer, J., Hannah, D. M., Howden, N. J. K., Wagener, T., and Worrall, F.: Catchment similarity concepts for understanding dynamic biogeochemical behaviour of river basins, Hydrological Processes, 28, 1554-1560, 10.1002/hyp.10093, 2014.

LaCroix, R. E., Tfaily, M. M., McCreight, M., Jones, M. E., Spokas, L., and Keiluweit, M.: Shifting mineral and redox controls on carbon cycling in seasonally flooded mineral soils, Biogeosciences, 16, 2573-2589, 10.5194/bg-16-2573-2019, 2019.

Larsen, S., Andersen, T., and Hessen, D. O.: Climate change predicted to cause severe increase of organic carbon in lakes, Global Change Biology, 17, 1186-1192, 10.1111/j.1365-2486.2010.02257.x, 2011.

660 Laudon, H., Kuglerova, L., Sponseller, R. A., Futter, M., Nordin, A., Bishop, K., Lundmark, T., Egnell, G., and Agren, A. M.: The role of biogeochemical hotspots, landscape heterogeneity, and hydrological connectivity for minimizing forestry effects on water quality, Ambio, 45 Suppl 2, 152-162, 10.1007/s13280-015-0751-8, 2016

Lê, S., Josse, J., and Husson, F.: FactoMineR: An R Package for Multivariate Analysis, 2008, 25, 18, 10.18637/jss.v025.i01, 2008.

Ledesma, J. L., Grabs, T., Bishop, K. H., Schiff, S. L., and Kohler, S. J.: Potential for long-term transfer of dissolved organic carbon from riparian zones to streams in boreal catchments, Glob Chang Biol, 21, 2963-2979, 10.1111/gcb.12872, 2015.

Ledesma, J. L., Futter, M. N., Laudon, H., Evans, C. D., and Kohler, S. J.: Boreal forest riparian zones regulate stream sulfate and dissolved organic carbon, Sci Total Environ, 560-561, 110-122, 10.1016/j.scitotenv.2016.03.230, 2016. 
Ledesma, J. L. J., Futter, M. N., Blackburn, M., Lidman, F., Grabs, T., Sponseller, R. A., Laudon, H., Bishop, K. H., and Kohler, S. J.: Towards an Improved Conceptualization of Riparian Zones in Boreal Forest Headwaters, Ecosystems, 21, 297-315, 10.1007/s10021017-0149-5, 2018a.

Ledesma, J. L. J., Kothawala, D. N., Bastviken, P., Maehder, S., Grabs, T., and Futter, M. N.: Stream Dissolved Organic Matter Composition Reflects the Riparian Zone, Not Upslope Soils in Boreal Forest Headwaters, Water Resources Research, 54, 3896-3912, 10.1029/2017wr021793, 2018b.

Manning, R., Griffith, J. P., Pigot, T., and Vernon-Harcourt, L. F.: On the flow of water in open channels and pipes, 1890.

675 Matilainen, A., Gjessing, E. T., Lahtinen, T., Hed, L., Bhatnagar, A., and Sillanpaa, M.: An overview of the methods used in the characterisation of natural organic matter (NOM) in relation to drinking water treatment, Chemosphere, 83, 1431-1442, 10.1016/j.chemosphere.2011.01.018, 2011.

Moeck, C., Hunkeler, D., and Brunner, P.: Tutorials as a flexible alternative to GUIs: An example for advanced model calibration using Pilot Points, Environmental Modelling \& Software, 66, 78-86, 10.1016/j.envsoft.2014.12.018, 2015.

680 Mostovaya, A., Hawkes, J. A., Dittmar, T., and Tranvik, L. J.: Molecular Determinants of Dissolved Organic Matter Reactivity in Lake Water, Frontiers in Earth Science, 5, 106, 10.3389/feart.2017.00106, 2017.

Musolff, A., Fleckenstein, J. H., Opitz, M., Buttner, O., Kumar, R., and Tittel, J.: Spatio-temporal controls of dissolved organic carbon stream water concentrations, Journal of Hydrology, 566, 205-215, 10.1016/j.jhydrol.2018.09.011, 2018.

Pinay, G., Peiffer, S., De Dreuzy, J. R., Krause, S., Hannah, D. M., Fleckenstein, J. H., Sebilo, M., Bishop, K., and Hubert-Moy, L.: Upscaling Nitrogen Removal Capacity from Local Hotspots to Low Stream Orders' Drainage Basins, Ecosystems, 18, 1101-1120, 10.1007/s10021015-9878-5, 2015.

Pisani, O., Bosch, D. D., Coffin, A. W., Endale, D. M., Liebert, D., and Strickland, T. C.: Riparian land cover and hydrology influence stream dissolved organic matter composition in an agricultural watershed, Sci Total Environ, 717, 137165, 10.1016/j.scitotenv.2020.137165, 2020.

690 Ploum, S. W., Laudon, H., Peralta-Tapia, A., and Kuglerová, L.: Are dissolved organic carbon concentrations in riparian groundwater linked to hydrological pathways in the boreal forest?, Hydrol. Earth Syst. Sci., 24, 1709-1720, 10.5194/hess-24-1709-2020, 2020.

Prairie, Y. T.: Carbocentric limnology: looking back, looking forward, Canadian Journal of Fisheries and Aquatic Sciences, 65, 543-548, 10.1139/f08-011, 2008.

R-Core-Team: R: A Language and Environment for Statistical Computing, in, R Foundation for Statistical Computing, 2017.

695 Raeke, J., Lechtenfeld, O. J., Tittel, J., Oosterwoud, M. R., Bornmann, K., and Reemtsma, T.: Linking the mobilization of dissolved organic matter in catchments and its removal in drinking water treatment to its molecular characteristics, Water Res, 113, 149-159, 10.1016/j.watres.2017.01.066, 2017.

Raymond, P. A., Hartmann, J., Lauerwald, R., Sobek, S., McDonald, C., Hoover, M., Butman, D., Striegl, R., Mayorga, E., Humborg, C., Kortelainen, P., Dürr, H., Meybeck, M., Ciais, P., and Guth, P.: Global carbon dioxide emissions from inland waters, Nature, 503, 355359, 10.1038/nature12760, 2013.

Rousseeuw, P. J.: Silhouettes - a Graphical Aid to the Interpretation and Validation of Cluster-Analysis, Journal of Computational and Applied Mathematics, 20, 53-65, 10.1016/0377-0427(87)90125-7, 1987.

Seifert, A. G., Roth, V. N., Dittmar, T., Gleixner, G., Breuer, L., Houska, T., and Marxsen, J.: Comparing molecular composition of dissolved organic matter in soil and stream water: Influence of land use and chemical characteristics, Sci Total Environ, 571, 142-152, 10.1016/j.scitotenv.2016.07.033, 2016.

Shen, Y., Chapelle, F. H., Strom, E. W., and Benner, R.: Origins and bioavailability of dissolved organic matter in groundwater, Biogeochemistry, 122, 61-78, 10.1007/s10533-014-0029-4, 2015.

Sherene, T.: Mobility and transport of heavy metals in polluted soil environment, Biological Forum—An International Journal, 2010, 112121 ,

710 Stanley, E. H., Powers, S. M., Lottig, N. R., Buffam, I., and Crawford, J. T.: Contemporary changes in dissolved organic carbon (DOC) in human-dominated rivers: is there a role for DOC management?, Freshwater Biology, 57, 26-42, 10.1111/j.1365-2427.2011.02613.x, 2012.

Strohmeier, S., Knorr, K. H., Reichert, M., Frei, S., Fleckenstein, J. H., Peiffer, S., and Matzner, E.: Concentrations and fluxes of dissolved organic carbon in runoff from a forested catchment: insights from high frequency measurements, Biogeosciences, 10, 905-916, 10.5194/bg-10-905-2013, 2013.

Tang, Q., Kurtz, W., Schilling, O. S., Brunner, P., Vereecken, H., and Franssen, H. J. H.: The influence of riverbed heterogeneity patterns on river-aquifer exchange fluxes under different connection regimes, Journal of Hydrology, 554, 383-396, 10.1016/j.jhydrol.2017.09.031, 2017.

Tarboton, D. G.: A new method for the determination of flow directions and upslope areas in grid digital elevation models, Water Resources Research, 33, 309-319, 10.1029/96wr03137, 1997.

Tfaily, M. M., Wilson, R. M., Cooper, W. T., Kostka, J. E., Hanson, P., and Chanton, J. P.: Vertical Stratification of Peat Pore Water Dissolved Organic Matter Composition in a Peat Bog in Northern Minnesota, Journal of Geophysical Research: Biogeosciences, 123, 479-494, 10.1002/2017jg004007, 2018. 
Therrien, R., McLaren, R., Sudicky, E., and Panday, S.: HydroGeoSphere: A three-dimensional numerical model describing fully-integrated subsurface and surface flow and solute transport, Groundwater Simulations Group, University of Waterloo, Waterloo, ON, 2010.

Wagner, S., Fair, J. H., Matt, S., Hosen, J. D., Raymond, P., Saiers, J., Shanley, J. B., Dittmar, T., and Stubbins, A.: Molecular Hysteresis: Hydrologically Driven Changes in Riverine Dissolved Organic Matter Chemistry During a Storm Event, Journal of Geophysical Research: Biogeosciences, 124, 759-774, 10.1029/2018jg004817, 2019.

Wang, X., Zhang, H., Zhang, Y., Shi, Q., Wang, J., Yu, J., and Yang, M.: New Insights into Trihalomethane and Haloacetic Acid Formation Potentials: Correlation with the Molecular Composition of Natural Organic Matter in Source Water, Environmental Science \& Technology, 51, 2015-2021, 10.1021/acs.est.6b04817, 2017.

Wen, H., Perdrial, J., Abbott, B. W., Bernal, S., Dupas, R., Godsey, S. E., Harpold, A., Rizzo, D., Underwood, K., Adler, T., Sterle, G., and Li, L.: Temperature controls production but hydrology regulates export of dissolved organic carbon at the catchment scale, Hydrology and Earth System Sciences, 24, 945-966, 10.5194/hess-24-945-2020, 2020.

735 Werner, B. J., Musolff, A., Lechtenfeld, O. J., de Rooij, G. H., Oosterwoud, M. R., and Fleckenstein, J. H.: High-frequency measurements explain quantity and quality of dissolved organic carbon mobilization in a headwater catchment, Biogeosciences, 16, 4497-4516, 10.5194/bg-16-4497-2019, 2019.

Werner, B. J. (2021). High resolution spatial, chemical (dissolved organic carbon) and hydrological dataset of the upper Rappbode Catchment in the temperate Harz Mountains, Germany, HydroShare, https://doi.org/10.4211/hs.b32ba184414e475ba36a0bb193866ef1.

740 Wilske, C., Herzsprung, P., Lechtenfeld, O. J., Kamjunke, N., and von Tumpling, W.: Photochemically Induced Changes of Dissolved Organic Matter in a Humic-Rich and Forested Stream, Water, 12, 331, 10.3390/w12020331, 2020.

Wilson, H. F., and Xenopoulos, M. A.: Effects of agricultural land use on the composition of fluvial dissolved organic matter, Nature Geoscience, 2, 37-41, 10.1038/ngeo391, 2008.

Yang, J., Graf, T., and Ptak, T.: Impact of climate change on freshwater resources in a heterogeneous coastal aquifer of Bremerhaven, Germany: A three-dimensional modeling study, J Contam Hydrol, 177-178, 107-121, 10.1016/j.jconhyd.2015.03.014, 2015.

Yang, J., Heidbuchel, I., Musolff, A., Reinstorf, F., and Fleckenstein, J. H.: Exploring the Dynamics of Transit Times and Subsurface Mixing in a Small Agricultural Catchment, Water Resources Research, 54, 2317-2335, 10.1002/2017wr021896, 2018.

Zarnetske, J. P., Bouda, M., Abbott, B. W., Saiers, J., and Raymond, P. A.: Generality of Hydrologic Transport Limitation of Watershed Organic Carbon Flux Across Ecoregions of the United States, Geophysical Research Letters, 45, 11702-11711, 10.1029/2018gl080005, 2018 . 